\title{
Interactive Regimes of Reduced
} Irrigation and Salt Stress Depressed Tomato Water Use Efficiency at Leaf and Plant Scales by Affecting Leaf Physiology and Stem Sap Flow

\author{
Hui Yang ${ }^{1}$, Manoj K. Shukla ${ }^{2}$, Xiaomin Mao ${ }^{1}$, Shaozhong Kang ${ }^{1}$ and Taisheng Du ${ }^{1 *}$ \\ ${ }^{1}$ Center for Agricultural Water Research in China, China Agricultural University, Beijing, China, ${ }^{2}$ Plant and Environmental \\ Sciences Department, New Mexico State University, Las Cruces, NM, United States
}

OPEN ACCESS

Edited by:

Bhabani S. Das,

Indian Institute of Technology

Kharagpur, India

Reviewed by:

Alejandra Navarro, Council for Agricultural and Economics Research, Italy Marcella Michela Giuliani, University of Foggia, Italy

*Correspondence: Taisheng Du

dutaisheng@cau.edu.cn

Specialty section: This article was submitted to

Plant Physiology,

a section of the journal

Frontiers in Plant Science

Received: 25 September 2018 Accepted: 29 January 2019

Published: 28 February 2019

Citation:

Yang H, Shukla MK, Mao X, Kang S and Du T (2019) Interactive Regimes of Reduced Irrigation and Salt Stress

Depressed Tomato Water Use Efficiency at Leaf and Plant Scales by Affecting Leaf Physiology and Stem Sap Flow. Front. Plant Sci. 10:160. doi: 10.3389/fp/s.2019.00160
Interactive effects of reduced irrigation and salt stress on leaf physiological parameters, biomass accumulation, and water use efficiency (WUE) of tomato plants at leaf and whole plant scales were investigated in a field experiment during 2016 and a greenhouse experiment during 2017. Experiment utilized two irrigation regimes (full, $2 / 3$ of full irrigation) and four soil salt regimes $(0,0.3,0.6,0.9 \%$ in 2016 season; and 0, 0.2, 0.3, $0.4 \%$ in 2017 season). Three salts, sodium chloride, magnesium sulfate, and calcium sulfate (mass ratio of 2:2:1), were homogeneously mixed with soil prior to packing into containers $\left(0.024 \mathrm{~m}^{3}\right)$. Li-COR 6400 was used to measure tomato leaf physiological parameters. Instantaneous water use efficiency (WUE $\mathrm{E}_{\text {ins }}, \mu \mathrm{mol} \mathrm{mmol}^{-1}$ ) and intrinsic water use efficiency $\left(W E_{i n t}, \mu \mathrm{mol} \mathrm{mol}{ }^{-1}\right)$ were determined at leaf scale, yield water use efficiency $\left(W U E_{Y}, g L^{-1}\right.$ ), and dry biomass water use efficiency (WUE $E_{D M}, g L^{-1}$ ) were determined at whole plant scale. Plants irrigated with $2 / 3$ of full irrigation with zero soil-salt treatment had higher dry biomass and yield per plant, resulting in the highest WUE $E_{D M}$ and $W U E_{Y}$ at whole plant scale. Increasing soil salinity decreased dry biomass and yield, leading to greater decreases in whole plant WUE $E_{D M}$ and WUEY under both irrigation treatments. At full irrigation, no decreases in stomatal conductance $\left(g_{s}, \mathrm{~mol} \mathrm{~m}^{-2} \mathrm{~s}^{-1}\right.$ ) and slight increase in photosynthetic rate $\left(P_{n}, \mu \mathrm{mol} \mathrm{m}^{-2} \mathrm{~s}^{-1}\right)$ led to higher WUE $E_{\text {int }}$ at leaf scale during both years. Under full and reduced irrigation, increasing soil salt content decreased $P_{n}$ and transpiration rate $\left(T_{r}, \mathrm{mmol} \mathrm{m}^{-2} \mathrm{~s}^{-1}\right)$ and led to reductions in WUE $E_{\text {ins }}$ at the leaf scale. However, compared to full irrigation, reduced irrigation improved WUE $\mathrm{E}_{\text {ins }}$ with a significant decline in $T_{r}$ in no salt and $0.3 \%$ soil-salt treatments during both years. For soil salt content of $0.6 \%$, stomatal limitation due to salt stress resulted in higher WUE $_{\text {int }}$, but soil salt content of $0.9 \%$ decreased WUE $E_{\text {int }}$ due to non-stomatal limitation. Soil salt content significantly decreased sap flow, with the maximum variation of daily sap flow per plant of 7.96-31.37 g/h in 2016 and 12.52-36.02 $\mathrm{g} \mathrm{h}^{-1}$ in 2017. Sap flow rate 
was linearly related to air temperature $\left(T_{a},{ }^{\circ} \mathrm{C}\right)$, solar radiation $\left(R_{s}, W^{-2}\right)$, and vapor pressure deficit (VPD, $\mathrm{kPa}$ ). These results advance knowledge on tomato response to abiotic stresses and could improve management of tomato production in water- and salt-stressed areas.

Keywords: reduced irrigation, salt stress, tomato, water use efficiency, sap flow, soil moisture

\section{INTRODUCTION}

Appropriate water-saving irrigation regimes are needed to alleviate the threat of water shortage and severe drought on food security under increasing population worldwide (Wei et al., 2016), especially in ecologically fragile arid and semiarid areas. More than $6 \%$ of the world's land is subject to salinity problems (Unesco Water Portal, 2007), and the use of water-saving strategies could exacerbate secondary salinization. Approximately $20 \%$ of irrigated land was affected by salinity where crop yields were notably reduced (Qadir et al., 2014). Therefore, soil salinity measurements must precede implementation of water-saving irrigation regimes (ReinaSánchez et al., 2005). Increases in the duration of droughts have necessitated the use of lower quality groundwater to supplement irrigation in semi-arid regions (Flores et al., 2016, 2017; Baath et al., 2017). Understanding plant responses to coupled abiotic stresses of water and salinity, and the underlying mechanisms of improving WUE from leaf to whole plant scale, would be useful to stabilize crop performance and production under drought and saline conditions in a changing climate.

Salinity-induced morphological and physiological changes in plants are mostly identical to drought during osmotic stress phase (Munns, 2002). Drought and salinity stresses cause progressive reductions of water use, leaf growth, and yield via restriction on stomatal apertures to mediate leaf photochemistry and carbon metabolism (Negrão et al., 2017). Under salinity stress, plants could suffer due to salt-specific effects of ion toxicity (Deb et al., 2013; Farooq et al., 2015). Most of the experiments reported so far were conducted under simulated conditions of using either hydroponic culture with different gradients of nutritive solutions (Albaladejo et al., 2017) or soil irrigated with different levels of saline solutions of $\mathrm{NaCl}$ (Ahmed et al., 2013; Galli et al., 2016), $\mathrm{NaCl}$ and $\mathrm{CaCl}_{2}$ (Katerji et al., 2011), or brackish groundwater (Flores et al., 2016; Baath et al., 2017).

It is more realistic for plant roots to be exposed to multiple salts simultaneously due to the specific ion effects as wells as competitions among ions (Farooq et al., 2015), but very few studies have been conducted in soil containing salt. Schiattone et al. (2017) mixed two salts $\left(\mathrm{NaCl}\right.$ and $\left.\mathrm{CaCl}_{2}\right)$ with soil to investigate water use and rocket crop performance under different salt-stressed conditions. The results showed that the increasing soil salt content decreased leaf size and numbers, water use, and yield. Faster uptake and transport from roots to the shoots of ions in solution caused symptoms to occur early in tomato leaves (Albaladejo et al., 2017). $\mathrm{Na}^{+}$interfered with $\mathrm{K}^{+}$uptake causing disturbance in stomatal regulations (Siddiqi et al., 2011) and also stimulated sulfate uptake of safflower plant (Patil, 2012).

Plant acclimation to water stress is the result of osmotic adjustment by chemical growth regulators in roots which maintain plants water status with little influence on photosynthetic rate (Martínez et al., 2007; Chaves et al., 2009; Du et al., 2015; Negrão et al., 2017). In addition, plant adaptation to salinity causes adjustments in ion uptake, extrusion, and sequestration as well as synthesis of compatible solutes to maintain cellular homeostasis (Chaves et al., 2009). Some salt-tolerant species are better able to maintain a longer greenness and photosynthetic process under high levels of $\mathrm{Na}^{+}$ concentration in tissues (Flores et al., 2016; Negrão et al., 2017). However, response to individual stress factors cannot be isolated from plant response (Mittler, 2006).

Another challenge is linking changes in leaf physiology to WUE at leaf and whole plant scales. Reduced irrigation has been reported to improve WUE at plant scale by maintaining yield (Chen et al., 2013; Cosić et al., 2015; Yang et al., 2017). WUE at leaf scale is impacted by external factors, e.g., VPD and soil water content, and internal factors, e.g., stomatal conductance, leaf mesophyll conductance, and leaf water deficit (Chaves et al., 2009; Niu et al., 2011). Instantaneous water use efficiency $\left(\mathrm{WUE}_{\text {ins }}, \mu \mathrm{mol} \mathrm{mmol}{ }^{-1}\right.$ ) is reported to decrease with increasing rainfall (Farquhar and Sharkey, 1982) while intrinsic water use efficiency (WUE $\mathrm{Wnt}_{\mathrm{int}}, \mu \mathrm{mol} \mathrm{mol}^{-1}$ ) is improved by sustaining $\mathrm{P}_{\mathrm{n}}$ or decreasing $\mathrm{g}_{\mathrm{s}}$ (Wang et al., 2010).

Tomato is moderately tolerant to salinity, with a threshold saturated paste EC of $1.3 \sim 6 \mathrm{dS} \mathrm{m}^{-1}$ (Maggio et al., 2004). The marketable yield and dry matter of tomato decrease with salinity (Reina-Sánchez et al., 2005). Dry biomass water use efficiency (WUE $E_{\mathrm{DM}}, \mathrm{g} \mathrm{L}^{-1}$ ) of tomato plants did not differ at 35 and $70 \mathrm{mM} \mathrm{NaCl}$ compared to control (Romero-Aranda et al., 2001). In contrast, Reina-Sánchez et al. (2005) found that WUE of four tomato cultivars slightly improved, while yield water use efficiency (WUE, $\mathrm{g} \mathrm{L}^{-1}$ ) decreased with increasing salinity (Zhang et al., 2016). However, water use efficiency (WUE $E_{\text {ins }}$ and $\left.\mathrm{WUE}_{\mathrm{int}}\right)$ at leaf scale for tomato species under salt-stressed conditions are still unknown.

Generally, sap flow rate is affected by various internal and external factors. Internal factors refer to plant water status, i.e., canopy structure, stomatal aperture, stem hydraulic structure, and hydraulic conductivity of roots; and external

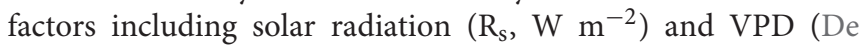
Swaef and Steppe, 2010; Liu et al., 2010). Only a few studies have documented that sap flow of tomato plants significantly decreased in deficit-irrigated treatments (Liu et al., 2010; Qiu et al., 2015; Mao et al., 2017). 
Tomato is widely planted in northwest China. However, with increasing tomato consumption and decreasing water resources in northwest China, greenhouse tomato cultivation has shown a large potential. Therefore, in this study, one field experiment and one greenhouse experiment were conducted in 2016 and 2017 , respectively. Our hypotheses were that reduced irrigation coupled with salt stress will decrease tomato sap flow rate and the WUE will improve under water stress with/without mild salt stress at leaf and plant levels. The objectives were to (1) investigate the influence of simultaneous water and salt stresses on $\mathrm{WUE}_{\text {ins }}$ and $\mathrm{WUE}_{\text {int }}$ at leaf and plant scale, (2) evaluate actual transpiration of tomato under different water and salt treatments, and (3) determine tomato WUE from leaf scale to plant scale under different water and salt stresses.

\section{MATERIALS AND METHODS}

\section{Experimental Setup}

Two experiments were carried out, one in a field and another in a solar greenhouse $200 \mathrm{~m}$ away from the field, at the Shiyanghe Experimental Station of Crop Water Use, Wuwei city of northwest China $\left(37^{\circ} 52^{\prime} \mathrm{N}, 102^{\circ} 50^{\prime} \mathrm{E}, 1581 \mathrm{~m}\right.$ above sea level). The field experiment was conducted from May to August 2016 (2016 season) and the greenhouse experiment from April to August 2017 (2017 season). The greenhouse was 76 $\times 8 \mathrm{~m}$ in size and made of a steel frame covered with 0.2 $\mathrm{mm}$ thick polyethylene, with no heating or cooling system. A narrow ventilation on the roof controled the interior daytime temperature in the summer.

The pink series tomato (Lycopersicon esculentum, cultivars "Nathen" and "Jinpeng") were grown in the 2016 and 2017 seasons; both are common indeterminate tomato cultivars widely used in local tomato production. During both field and greenhouse experiments, the seedlings were transplanted at the $3 \mathrm{rd}$ to 4 th leaf stage into $7.8 \mathrm{~L}$ plastic containers $(35 \mathrm{~cm}$ top diameter, $30 \mathrm{~cm}$ bottom diameter, and $25 \mathrm{~cm}$ depth) filled with $16 \mathrm{~kg}$ air-dried sandy loam soil $(<5 \mathrm{~mm})$ with a bulk density of $1.3 \pm 0.5 \mathrm{~g} \mathrm{~cm}^{-3}$. During both years, cheesecloth and $1 \mathrm{~kg}$ of small gravel were packed at the bottom of the container to prevent soil loss. The containers were buried in the ground up to the top edge to maintain a soil temperature similar to the field. Soil surface of each container was covered with white polyethylene film to prevent soil water evaporation. The fertilizers applied were $200 \mathrm{mg} \mathrm{kg}^{-1}$ soil $\mathrm{N}\left(\mathrm{CH}_{4} \mathrm{~N}_{2} \mathrm{O}\right), 390 \mathrm{mg}$ $\mathrm{kg}^{-1}$ soil $\mathrm{P}\left(\mathrm{Ca}\left(\mathrm{H}_{2} \mathrm{PO}_{4}\right)\right.$, and $55 \mathrm{mg} \mathrm{kg}^{-1}$ soil $\mathrm{K}\left(\mathrm{KH}_{2} \mathrm{PO}_{4}\right)$. All three fertilizers were mixed homogeneously with soil before filling the containers to support plant growth during both years. The sandy loam soil had an average in situ bulk density of $1.52 \mathrm{~g} \mathrm{~cm}^{-3}$, volumetric soil water content of $25.3 \%$ at pot waterholding capacity, electrical conductivity of $0.302 \mathrm{dS} \mathrm{m}^{-1}$, and pH of 7.88 (Table 1). Considering the cultivars' characteristics of indetermination, tomato plants were pinched when the third truss of flowers came out.

\section{Treatments}

Two levels of irrigation, full irrigation (W1) and reduced irrigation (W2/3, 2/3 of W1), were applied with four soil salt regimes during two experiments. In the field experiment of 2016, four salt treatments created were S0 (no salt added), S3 $(0.3 \%)$, S6 $(0.6 \%)$, and S9 $(0.9 \%)$, corresponding to the soil solution electrical conductivity $\left(\mathrm{EC}_{\mathrm{s}}\right)$ of $0.205,1.030,1.932$, and $2.597 \mathrm{dS} \mathrm{m} \mathrm{m}^{-1}$. Salt content in parentheses represents the mass ratio of total salts to air-dried soil. Three salts, sodium chloride $(\mathrm{NaCl})$, magnesium sulfate $\left(\mathrm{MgSO}_{4}\right)$, and calcium sulfate $\left(\mathrm{CaSO}_{4}\right)$, were homogeneously mixed with soil prior to packing into containers with the mass ratio of 2:2:1, respectively. In the greenhouse experiment of 2017, S6 and S9 salinity treatments were discontinued and replaced with S2 (0.2\%) and S4 (0.4\%) with $\mathrm{EC}_{\mathrm{s}}$ of 0.814 , and $1.326 \mathrm{dS} \mathrm{m}^{-1}$ because plants were almost dead under S6 and S9 treatments. The experiment design was a split plot with water treatments (two levels) as main plot and salt treatments (four levels) as subplot, each treatment has 10 and 20 containers in 2016 and 2017, respectively.

One tomato plant was transplanted to each container at the 3rd to 4th leaf stage on 9 May 2016 and 24 April 2017. Container spacing was $0.5 \times 0.4 \mathrm{~m}$, resulting in five plants per $\mathrm{m}^{2}$. A drip arrow irrigation system was employed with twodrop arrow emitters in each container. For each treatment, the irrigation volume was controlled by a plastic bucket with scales installed at the head of the drip pipes, and sand and mesh filters were installed to prevent emitter clogging. Tap water with an electrical conductivity of $0.62 \mathrm{dS} \mathrm{m}^{-1}$ was used for irrigation. The irrigation treatments started on June 5th in 2016 at flowering stage, and on May 5th in 2017 in the middle of vegetative stage. Tomato plants were irrigated to $90 \%$ of pot water-holding capacity for the full irrigation treatment when its average soil water content (observed by 5 TE sensors) decreased to $50 \pm 2 \%$ of pot water-holding capacity. Irrigation amounts and times for each treatment are listed in Table 2.

The entire growth period of tomato was divided into three stages, i.e., vegetative stage (transplant to first blossom), flowering stage (first blossom to first fruit set), and fruit development and ripening stage (first fruit set to harvesting). Details of growth periods and irrigations are shown in Table 2.

\section{Environmental Variables}

The meteorological factors, solar radiation $\left(\mathrm{R}_{\mathrm{s}}, \mathrm{W} \mathrm{m}^{-2}\right)$, relative humidity $(\mathrm{RH}, \%)$, air temperature $\left(\mathrm{T}_{\mathrm{a}},{ }^{\circ} \mathrm{C}\right)$, and vapor pressure deficit (VPD, $\mathrm{kPa}$ ), for field and greenhouse experiments are shown in Figure 1. In the field experiment of 2016, meteorological data were recorded every $15 \mathrm{~min}$ from a weather station (Weather Hawk, Campbell Scientific, USA) $50 \mathrm{~m}$ away from the experiment field. In the greenhouse experiment of 2017, an automatic weather station (HOBO, Onset Computer Corp., USA) was installed in the middle of the greenhouse and data were collected every $15 \mathrm{~min}$. VPD was calculated from $\mathrm{RH}$ and $\mathrm{T}_{\mathrm{a}}$ (Norman, 1998). To measure soil water content (SWC, $\mathrm{cm}^{3} \mathrm{~cm}^{-3}$ ), one 5TE sensor (Decagon Devices, Inc., USA) was installed at the depth of $15 \mathrm{~cm}$ in three randomly selected containers in each treatment in both experiments. The data were collected every $30 \mathrm{~min}$ by an EM50 data logger (Decagon Devices, Inc., USA). Sensors were calibrated by optimizing gravimetrically and sensor-measured volumetric water contents. 
TABLE 1 | Mean for some of the physiochemical properties of soil used for field experiment in 2016 and greenhouse experiment in 2017.

\begin{tabular}{|c|c|c|c|c|c|c|c|c|}
\hline Season & Soil texture & $\%$ Sand & $\%$ Silt & \% Clay & $\mathrm{pH}$ & $\begin{array}{l}\text { Bulk density } \\
\qquad\left(\mathrm{g} \mathrm{cm}^{-3}\right)\end{array}$ & $\begin{array}{l}\text { Field capacity } \\
\left(\mathrm{cm}^{3} \mathrm{~cm}^{-3}\right)\end{array}$ & $\begin{array}{l}\text { Soil conductivity } \\
\left(\mathrm{dS} \mathrm{m}^{-1}\right)\end{array}$ \\
\hline 2016 & Sandy loam & 50 & 45 & 5 & 7.96 & 1.52 & 0.258 & 0.205 \\
\hline 2017 & Sandy loam & 51 & 45 & 5 & 7.8 & 1.52 & 0.247 & 0.398 \\
\hline
\end{tabular}

TABLE 2 | Details of irrigation treatment during tomato growth period during 2016-2017.

\begin{tabular}{|c|c|c|c|c|c|}
\hline \multirow[t]{2}{*}{ Year } & \multirow{2}{*}{$\begin{array}{l}\text { Growth } \\
\text { stage }\end{array}$} & \multirow[t]{2}{*}{ Date (MM/DD) } & \multicolumn{2}{|c|}{ Irrigation amount (L) } & \multirow{2}{*}{$\begin{array}{l}\text { Irrigation } \\
\text { times (No.) }\end{array}$} \\
\hline & & & W2/3 & W1 & \\
\hline \multirow[t]{4}{*}{2016} & Vegetative & 05/09-06/05 & 10.7 & 10.7 & 8 \\
\hline & Flowering & 06/06-06/24 & 9.2 & 12.5 & 11 \\
\hline & $\begin{array}{l}\text { Fruit } \\
\text { development } \\
\text { and ripening }\end{array}$ & 06/25-08/11 & 22.7 & 32.5 & 22 \\
\hline & Whole & 05/09-08/11 & 39.7 & 52.7 & 41 \\
\hline \multirow[t]{4}{*}{2017} & Vegetative & $04 / 24-05 / 24$ & 6.9 & 8.2 & 8 \\
\hline & Flowering & 05/25-06/13 & 10.1 & 14.4 & 10 \\
\hline & $\begin{array}{l}\text { Fruit } \\
\text { development } \\
\text { and ripening }\end{array}$ & 06/14-08/09 & 30.6 & 42.8 & 35 \\
\hline & Whole & 04/24-08/09 & 47.6 & 62.4 & 53 \\
\hline
\end{tabular}

W1, full irrigation; W2/3, deficit irrigation received 2/3 of full irrigation amount; vegetative stage, transplant to the first blossom; flowering stage, first blossom to first fruit set; fruit development and ripening stage, first fruit set to harvesting.

\section{Leaf and Plant Measurements}

Leaf gas exchange parameters, including photosynthesis rate $\left(\mathrm{P}_{\mathrm{n}}, \mu \mathrm{mol} \mathrm{m} \mathrm{m}^{-2} \mathrm{~s}^{-1}\right)$, transpiration rate $\left(\mathrm{T}_{\mathrm{r}}, \mathrm{mmol} \mathrm{m}^{-2}\right.$ $\left.\mathrm{s}^{-1}\right)$, stomatal conductance $\left(\mathrm{g}_{\mathrm{s}}, \mathrm{mol} \mathrm{m} \mathrm{m}^{-2} \mathrm{~s}^{-1}\right)$, and the ratio of interacellular $\mathrm{CO}_{2}$ concentration $\left(\mathrm{C}_{\mathrm{i}}, \mu \mathrm{mol} \mathrm{CO}_{2} \mathrm{~mol}^{-1}\right)$ to atmospheric $\mathrm{CO}_{2}$ concentration $\left(\mathrm{C}_{\mathrm{a}}, \mu \mathrm{mol} \mathrm{CO}_{2} \mathrm{~mol}^{-1}\right)$ were determined on fully expanded upper leaves with three replications in each treatment using a Portable Photosynthesis System (LI-6400XT, LI-COR Corporation, USA). Measurements were conducted on random sunny days from 7:00 a.m. to 7:00 p.m. every $2 \mathrm{~h}$ on 22 July and 7 August in 2016 and 4 July, 11 July, and 9 August in 2017 at the fruit development and ripening stages. Instantaneous water use efficiency (WUE $\mathrm{W}_{\mathrm{ins}}, \mathrm{mmol} \mathrm{mol}^{-1}$ ) was defined as the ratio of $\mathrm{P}_{\mathrm{n}}$ to $\mathrm{T}_{\mathrm{r}}$ and instrinsic water use efficiency (WUE $\mathrm{Wn}_{\mathrm{n}}, \mu \mathrm{mol}$ $\mathrm{mol}^{-1}$ ) as the ratio of $\mathrm{P}_{\mathrm{n}}$ to $\mathrm{g}_{\mathrm{s}}$ (Bierhuizen and Slatyer, 1965; Sinclair et al., 1984).

Sap flow rates of tomato plants were measured using dynagages (SGB9, SGB13, Dynamax, USA) during fruit development and ripening stages with Stem Heat Balance (SHB) method. In this method a stem is wrapped in a heater coil emitting a constant energy flux. The supplied energy is dissipated by convection along the stem by sap flow transport. Therefore, by measuring the convective heat fluxes and the energy supply, the rate of water flux along a stem can be calculated (Trambouze and
Voltz, 2001). The dynagages were installed on the stems of plants between the third and fourth internode above the soil surface. Leaf branches beneath the fifth internode were removed and plastic film was placed to avoid stem transpiration. A CR1000 data logger (Campbell Scientific, USA) was used to collect data every $30 \mathrm{~s}$ and averaged every $15 \mathrm{~min}$. Consequently, hourly sap flow rate per plant $\left(\mathrm{Q}_{\mathrm{h}}, \mathrm{g} \mathrm{h}^{-1}\right)$ was obtained. Since the CR1000 had eight channels, two plants per treatment of W2/3 treatments were first randomly selected to monitor sap flow during 27 June to 6 July, and two plants per treatment of W1 treatments were then selected from 19 July to 28 July in the 2016 season. In 2017, one plant per treatment was selected for sap flow measurement between 25 June and 30 June.

Three tomato plants for each treatment were harvested on 11 August 2016 and 9 August 2017. All fresh fruits from the three plants in each treatment were collected and yield (Y, g per plant) was recorded using an electronic balance with accuracy of $0.01 \mathrm{~g}$ (ME2002E, Mettler Toledo, USA). Roots, stems, and leaves were seperately dried at $75^{\circ} \mathrm{C}$ in the oven to the constant weight and dry matter weight was recorded. Water use efficiency at plant scale $W_{U E}$ was calculated as the ratio of dry aboveground biomass to irrigation water per plant, and $\mathrm{WUE}_{\mathrm{Y}}$ as fresh yield to irrigation water per plant.

\section{Statistical Analyses}

Two-way analysis of variance was performed using SPSS version 23.0 (IBM Statistics) by year to evaluate the effects of irrigation and salt regimes, as well as their interactions on tomato leaf physiology parameters and WUE at different scales. Duncan's multiple range test was used to assess differences between treatments at $P=0.05$. Pearson correlation analysis was done for 13 parameters, including $W_{U E} E_{D M}, W_{U}$, WUE $E_{i n t}$, $\mathrm{WUE}_{\mathrm{ins}}, \mathrm{P}_{\mathrm{n}}, \mathrm{T}_{\mathrm{r}}, \mathrm{g}_{\mathrm{s}}, \mathrm{C}_{\mathrm{i}} / \mathrm{C}_{\mathrm{a}}$, yield, dry aboveground biomass, sap flow rate, irrigation amount, and SSC (Table 4). The values of leaf physiology parameters were daily averages of all measurements.

Principal component analysis (PCA) was used to evaluate the comprehensive WUE at different scales as affected by reduced irrigation and salt stress regimes. The standardized data included $W_{U E}$, WUEY, WUE $E_{\text {int }}$, and WUE $\mathrm{W}_{\text {ins. }}$ PCA was carried out using correlation matrix of SPSS version 23.0 after the KMO and Bartlett's test, and factors with eigenvalues $>1$ were retained. Using compute variables module in SPSS, PCs were determined and then maximum and minimum principal component for each treatment were calculated. Finally, a comprehensive score was determined for each treatment; the larger the score, the higher the performance of the treatment (Shukla et al., 2006; Wang et al., 2015). 


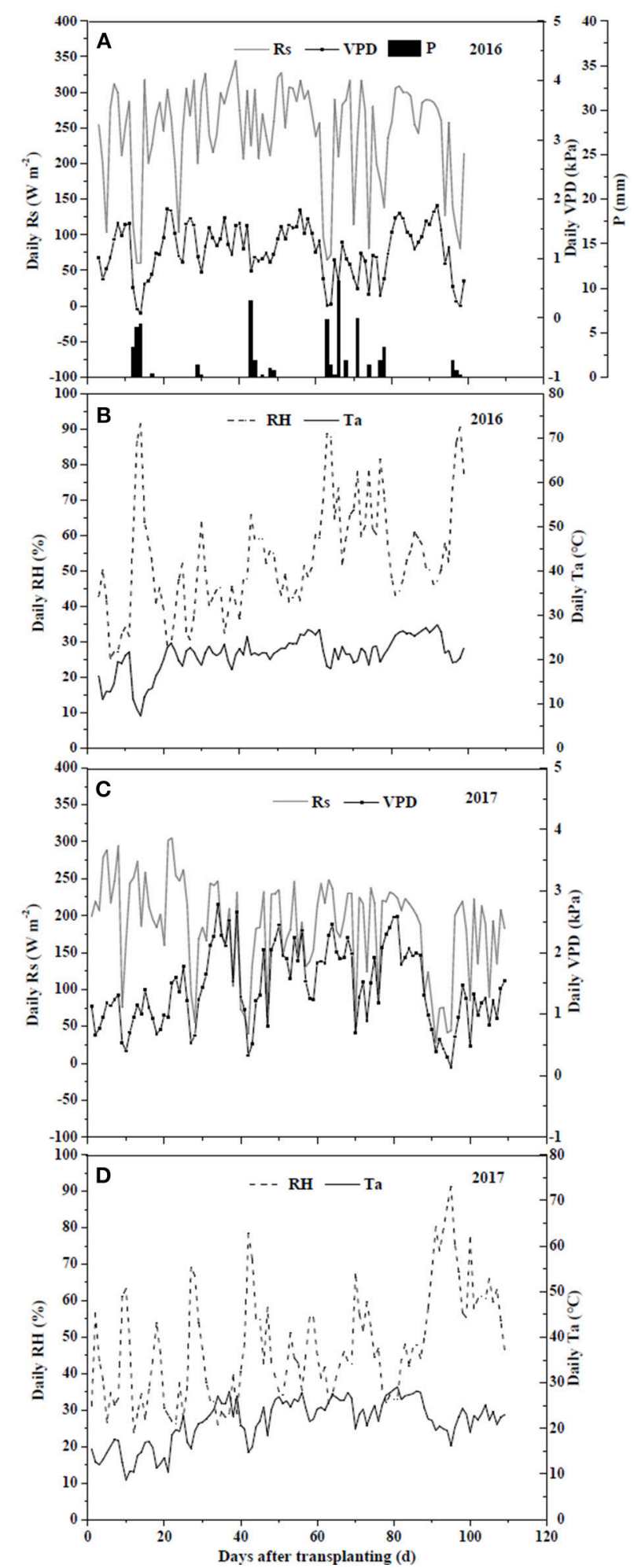

FIGURE 1 | Climate variances including daily solar radiation $\left(R_{S}\right)(\mathbf{A}, \mathbf{C})$, relative humidity $(\mathrm{RH})(\mathbf{B}, \mathbf{D})$, temperature $\left(\mathrm{T}_{\mathrm{a}}\right)(\mathbf{B}, \mathbf{D})$, and vapor pressure deficit $(\mathrm{VPD})$ (A,C) of field experiment in 2016 and greenhouse experiment in 2017.

\section{RESULTS}

\section{Environmental Variables}

In the field, $\mathrm{R}_{\mathrm{s}}$ ranged from $59.7 \mathrm{~W} \mathrm{~m}^{-2}$ on cloudy or rainy days to $327.8 \mathrm{~W} \mathrm{~m}^{-2}$ on sunny days, with an average of $243.1 \mathrm{~W} \mathrm{~m}^{-2}$ (Figure 1). RH, Ta and VPD varied from 25.3 to $91.6 \%$, from 7.2 to $27.8^{\circ} \mathrm{C}$, and from 0.08 to $1.89 \mathrm{kPa}$, with the averages of $53.0 \%, 21.0^{\circ} \mathrm{C}$ and $1.14 \mathrm{kPa}$, respectively. In the greenhouse, $\mathrm{R}_{\mathrm{s}}$ ranged from 28.2 to $305.1 \mathrm{~W} \mathrm{~m}^{-2}$, with an average of $171.8 \mathrm{~W}$ $\mathrm{m}^{-2}$. RH, Ta and VPD varied from 23.7 to $91.4 \%$, from 8.7 to $29.1^{\circ} \mathrm{C}$, and from 0.14 to $2.78 \mathrm{kPa}$, with the averages of $50.0 \%$, $23.7^{\circ} \mathrm{C}$ and $1.56 \mathrm{kPa}$, respectively. Variations of daily average SWC in the $0-20 \mathrm{~cm}$ soil profile under different irrigation and salt stress treatments during field and greenhouse experiments are presented in Figure 2. In the field experiment of 2016, SWC under W1S9 treatment was higher than W1S6, W1S3, and W1S0 treatments during the whole growth season because plants were severely stressed and uptake was very low. Under reduced irrigation, the variation of SWC among S0, S3, and S6 treatments decreased compared to full irrigation (Figures 2A,B). In the greenhouse experiment of 2017, SWC increased with increasing soil salt content under both full and reduced irrigation (Figures 2C,D).

\section{Yield and Dry Biomass Per Plant}

In the field experiment of 2016, dry biomass per plant of stem, leaf, root, and total as well as root/shoot ratio were significantly affected by soil salt treatments, while water treatments and the interaction of water and salt had no significant effects. Fresh fruit yield of tomato per plant was influenced by water and salt treatments, and their interaction (Table 3). Increasing soil salt content caused more yield reductions under both irrigation treatments. In the field experiment of 2016, reduced irrigation (W2/3) treatments produced higher yields compared to W1 under S0 and S3 treatments, while W2/3 treatments exacerbated yield reductions under S6 and S9 treatments. In the greenhouse experiment of 2017, since the gradient of soil salt treatments was reduced, salt treatments didnot show significant effects on dry biomass of stem, leaf, root, and root/shoot ratio. Only leaf biomass was affected by water treatments and the interaction of water and salt, and root/shoot ratio was influenced by water treatments. The effect of salt treatments on total biomass per plant was also significant. Yields showed similar trends with those in the field experiment of 2016 under water and salt treatments (Table 3). The proportions of stem, leaf, and root dry matter were about 45.5, 42.9, and 13.4\%, respectively (Figure 3).

\section{Gas Exchange Parameters}

All the gas exchange parameters $\mathrm{P}_{\mathrm{n}}, \mathrm{T}_{\mathrm{r}}, \mathrm{g}_{\mathrm{s}}$, and $\mathrm{C}_{\mathrm{i}} / \mathrm{C}_{\mathrm{a}}$ were significantly affected by irrigation regimes, salt treatment, and their interactions in both experiments (Table 3). In 2016, $\mathrm{P}_{\mathrm{n}}$ and $\mathrm{T}_{\mathrm{r}}$ decreased with increasing soil salt stress under both $\mathrm{W} 2 / 3$ and W1 treatments. However, in the greenhouse experiment of 2017, plants grown in salt treatments of S2 and S3 had notably 35.5 and $49.4 \%$ higher $\mathrm{P}_{\mathrm{n}}$, respectively, than those grown in S0 treatment 
Yang et al.

Salinity Decrease Tomato Water Use
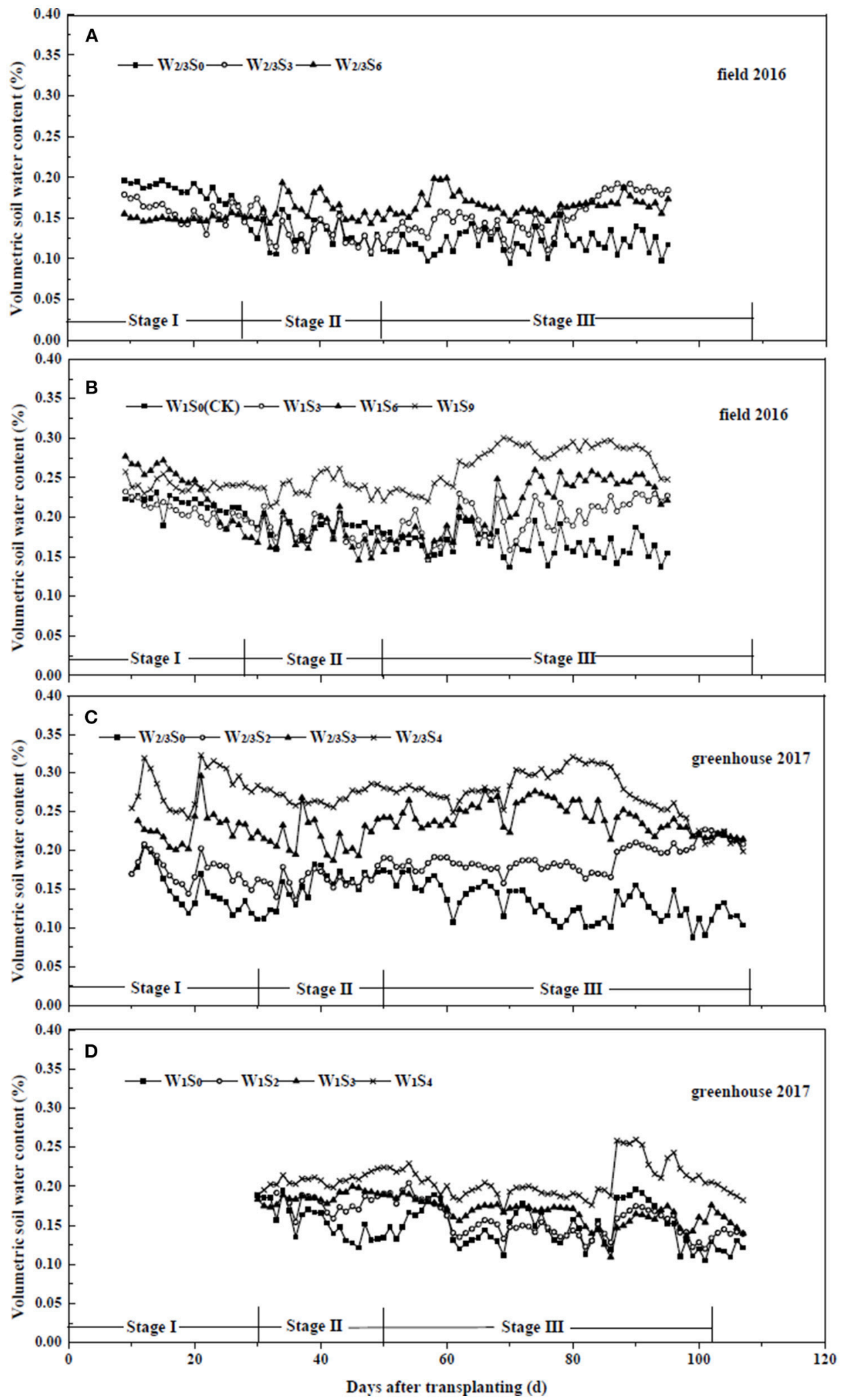

FIGURE 2 | Soil water content of tomato under different water and salt treatments in field experiment of 2016 (A,B) and greenhouse experiment of 2017 (C,D). Stage I: vegetative stage, Stage II: flowering stage, Stage III: fruit development and ripening stage.

Frontiers in Plant Science | www.frontiersin.org

6

February 2019 | Volume 10 | Article 160 


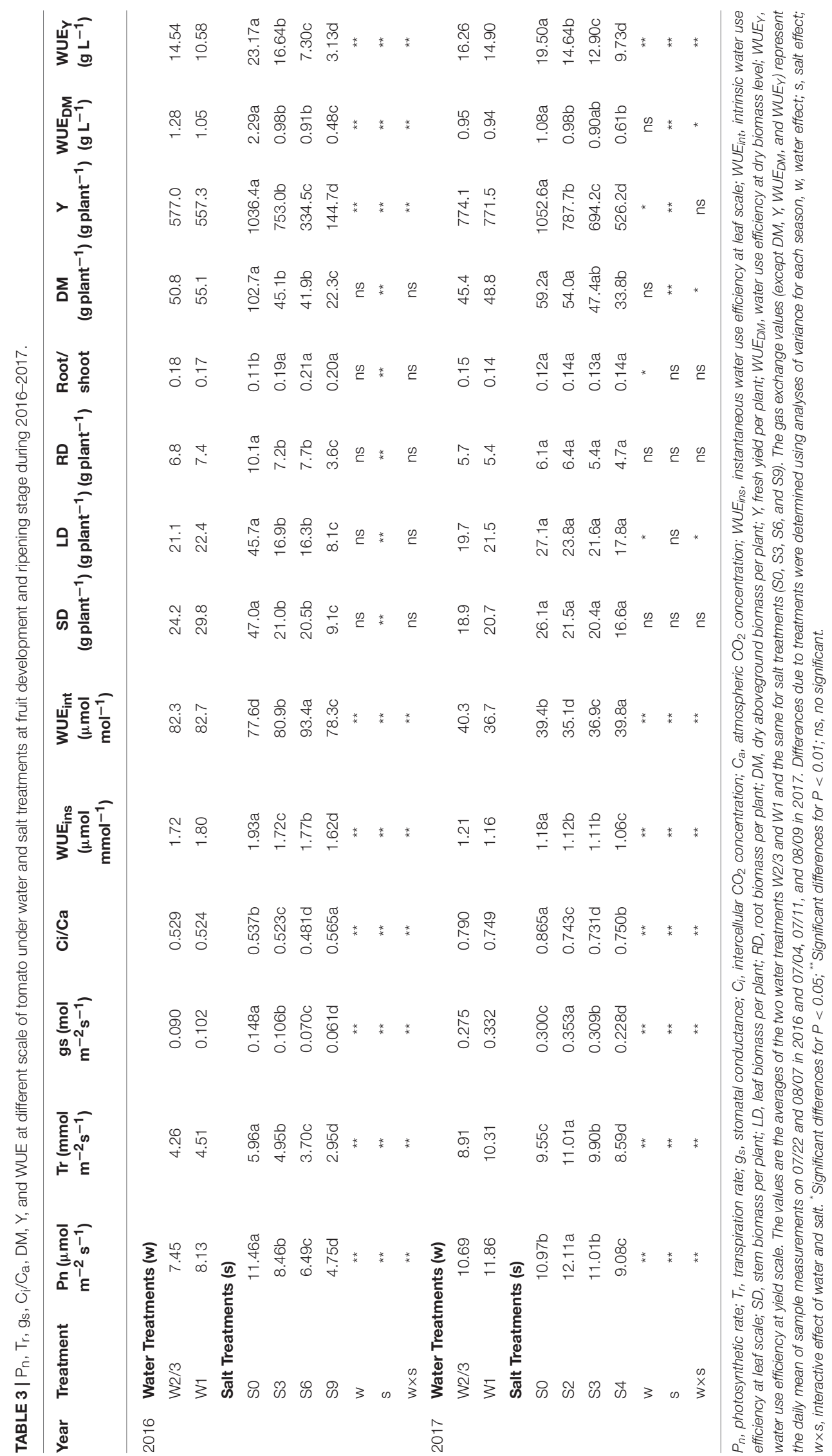



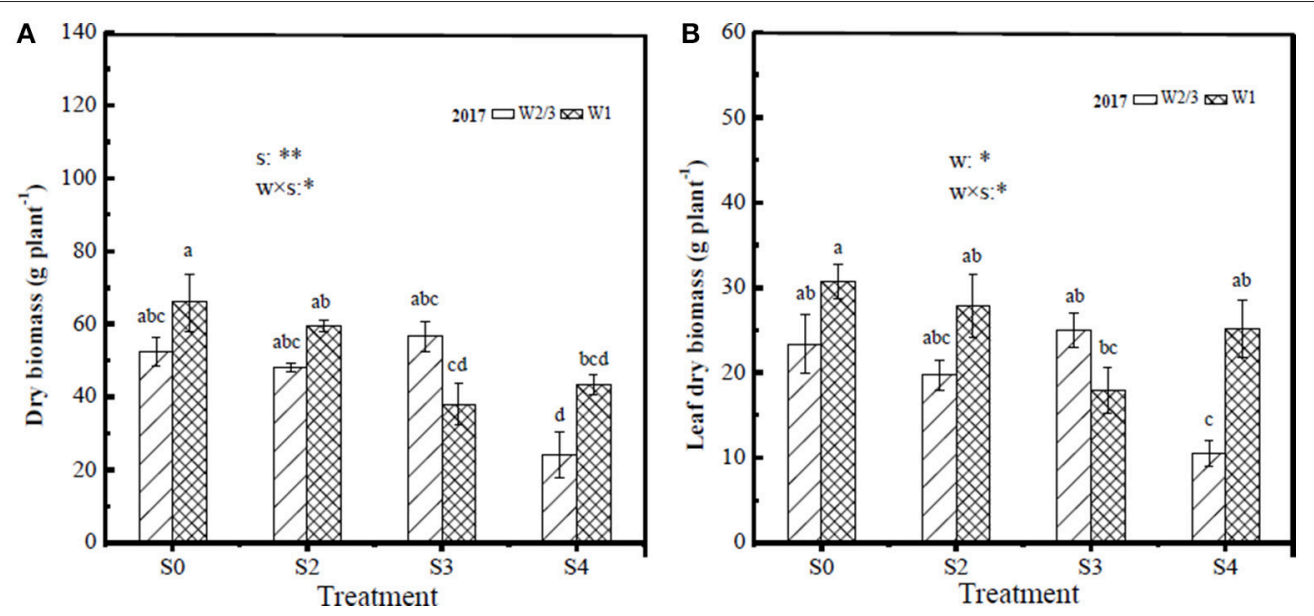

FIGURE 3 | Tomato dry biomass of whole plant (A) and leaf dry biomass (B) under different water and salt treatments at harvest in 2017 . Only the positive effects of the interactions $(\mathrm{W} \times \mathrm{s})$ are showed in the figure, $\mathrm{w}$, water treatments; $\mathrm{s}$, salt treatments, ${ }^{*}$ significant differences for $P<0.05$; ${ }^{\star \star}$ significant differences for $P<0.01$.

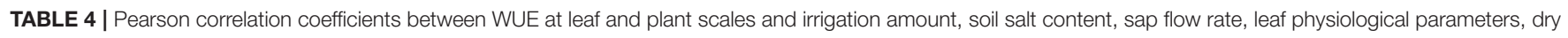
matter per plant, and fresh yield per plant.

\begin{tabular}{|c|c|c|c|c|c|c|c|c|c|c|c|c|}
\hline Index & $\begin{array}{c}\text { WUE }_{\text {ins }} \\
(\mu \mathrm{mol} \\
\left.\mathrm{mmol}^{-1}\right)\end{array}$ & $\begin{array}{c}\text { WUE }_{\text {int }} \\
(\mu \mathrm{mol} \\
\left.\mathrm{mol}^{-1}\right)\end{array}$ & $\begin{array}{l}\text { WUEDM } \\
\left(g L^{-1}\right)\end{array}$ & $\begin{array}{l}\text { WUEY } \\
\left(g L^{-1}\right)\end{array}$ & I (L) & SSC (\%) & $\begin{array}{l}P_{n}(\mu \mathrm{mol} \\
\left.m^{-2} s^{-1}\right)\end{array}$ & $\begin{array}{c}T_{r}(\mathrm{mmol} \\
\left.\mathrm{m}^{-2} \mathrm{~s}^{-1}\right)\end{array}$ & $\begin{array}{c}\mathrm{gs}_{\mathrm{s}}(\mathrm{mol} \\
\mathrm{m}^{-2} \\
\left.\mathrm{~s}^{-1}\right)\end{array}$ & $\mathrm{C}_{\mathrm{i}} / \mathrm{C}_{\mathrm{a}}$ & $\begin{array}{c}\text { DM } \\
\text { (g plant }^{-1}\end{array}$ & $\begin{array}{c}Y \\
\left(\text { g plant }^{-1}\right)\end{array}$ \\
\hline$W_{U} E_{\text {int }}\left(\mu \mathrm{mol} \mathrm{mol}{ }^{-1}\right)$ & $0.934^{\star \star}$ & & & & & & & & & & & \\
\hline WUEDM $\left(g L^{-1}\right)$ & 0.454 & 0.185 & & & & & & & & & & \\
\hline WUEY $\left(\mathrm{g} \mathrm{L}^{-1}\right)$ & 0.130 & -0.139 & $0.803^{\star \star}$ & & & & & & & & & \\
\hline Irrigation amount (L) & $-0.569^{\star}$ & $-0.558^{\star}$ & -0.265 & -0.192 & & & & & & & & \\
\hline Soil salt content (\%) & 0.169 & 0.423 & $-0.639^{\star *}$ & $-0.882^{\star \star}$ & -0.213 & & & & & & & \\
\hline$P_{n}\left(\mu \mathrm{mol} m^{-2} s^{-1}\right)$ & -0.390 & $-0.648^{\star \star}$ & -0.467 & $0.620^{*}$ & 0.365 & $-0.827^{\star \star}$ & & & & & & \\
\hline$T_{r}\left(m m o l ~ m^{-2} s^{-1}\right)$ & $-0.801^{\star \star}$ & $-0.918^{\star \star}$ & 0.030 & 0.279 & $0.597^{\star}$ & $-0.586^{*}$ & $0.850^{\star \star}$ & & & & & \\
\hline$g_{s}\left(m o l m^{-2} s^{-1}\right)$ & $-0.766^{\star \star}$ & $-0.896^{\star \star}$ & 0.033 & 0.260 & $0.543^{*}$ & $-0.540^{*}$ & $0.846^{\star \star}$ & $0.986^{\star \star}$ & & & & \\
\hline $\mathrm{C}_{\mathrm{i}} / \mathrm{C}_{\mathrm{a}}$ & $-0.841^{\star \star}$ & $-0.892^{\star \star}$ & -0.190 & 0.206 & 0.417 & -0.430 & 0.462 & $0.730^{\star \star}$ & $0.716^{\star \star}$ & & & \\
\hline DM (g plant ${ }^{-1}$ ) & 0.298 & 0.011 & $0.939^{\star \star}$ & $0.764^{\star \star}$ & 0.047 & $-0.752^{\star \star}$ & $0.638^{\star \star}$ & 0.239 & 0.233 & -0.055 & & \\
\hline Y $\left(\mathrm{g} \mathrm{plant}^{-1}\right)$ & -0.098 & -0.366 & $0.686^{\star \star}$ & $0.930^{\star \star}$ & 0.150 & $-0.981^{\star *}$ & $0.782^{\star \star}$ & $0.521^{*}$ & 0.490 & 0.393 & $0.771^{\star \star}$ & \\
\hline Sap flow rate $\left(\mathrm{g} \mathrm{h}^{-1}\right)$ & 0.175 & -0.042 & 0.480 & 0.396 & 0.489 & $-0.577^{\star}$ & 0.526 & 0.258 & 0.252 & 0.031 & $0.684^{\star \star}$ & $0.581^{*}$ \\
\hline
\end{tabular}

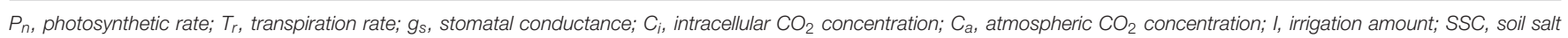

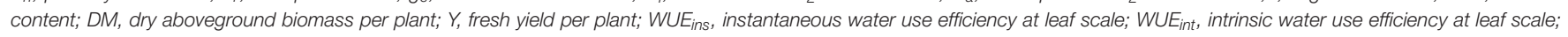

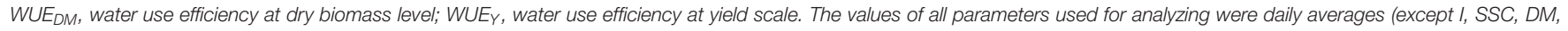
and Y) collected during 2016-2017.

*Significant differences for $P<0.05$; ${ }^{\star}$ Significant differences for $P<0.01$.

under reduced irrigation regime (W2/3). For W1 treatment, highest $P_{n}$ of $13.30 \mu \mathrm{mol} \mathrm{m}^{-2} \mathrm{~s}^{-1}$ was for S0 treatment (Table 3). Moreover, $\mathrm{T}_{\mathrm{r}}$ was significantly positively correlated with $\mathrm{P}_{\mathrm{n}}$ and $\mathrm{g}_{\mathrm{s}}$ and was also notably correlated with $\mathrm{P}_{\mathrm{n}}$ and $\mathrm{T}_{\mathrm{r}}$ (Table 4). Although irrigation amount and soil salt content notably affected $\mathrm{C}_{\mathrm{i}} / \mathrm{C}_{\mathrm{a}}$ (Table 3), Pearson correlation coefficients between $\mathrm{C}_{\mathrm{i}} / \mathrm{C}_{\mathrm{a}}$, irrigation amount and soil salt content were not significant; $C_{i} / C_{a}$ had significant positive correlation with $\mathrm{T}_{\mathrm{r}}$ and $\mathrm{g}_{\mathrm{s}}$ (Table 4).

In 2016, diurnal variations of $P_{n}$ and $g_{s}$ in $S 0$ treatment under $\mathrm{W} 2 / 3$ and $\mathrm{W} 1$ regimes initially showed an increase from 7:00 to 9:00 a.m. and a decrease until 3:00 p.m.; however, multiple peaks were observed around 5:00 p.m., compensation of mild salt stress
(S3) in $\mathrm{P}_{\mathrm{n}}$ was more obvious than that of $\mathrm{S} 0$ (Figures $4 \mathrm{~A}, \mathbf{B}, \mathbf{E}, \mathbf{F}$ ). In 2017 , the diurnal variations of $g_{s}$ under various water and salt treatments showed a single-peak curve with the peak occurring at 10:00 a.m. (Figures 5E,F), and $\mathrm{T}_{\mathrm{r}}$ remained relatively high between 10:00 a.m. and 2:00 p.m. (Figures 5C,D), which was consistent with the results in the field experiment during 2016 (Figures 4C,D).

\section{Sap Flow Variation}

The daily variations of sap flow rate per plant under irrigation and salt treatments varied diurnally. Sap flow increased significantly from early morning (7:00 a.m.), reached the 

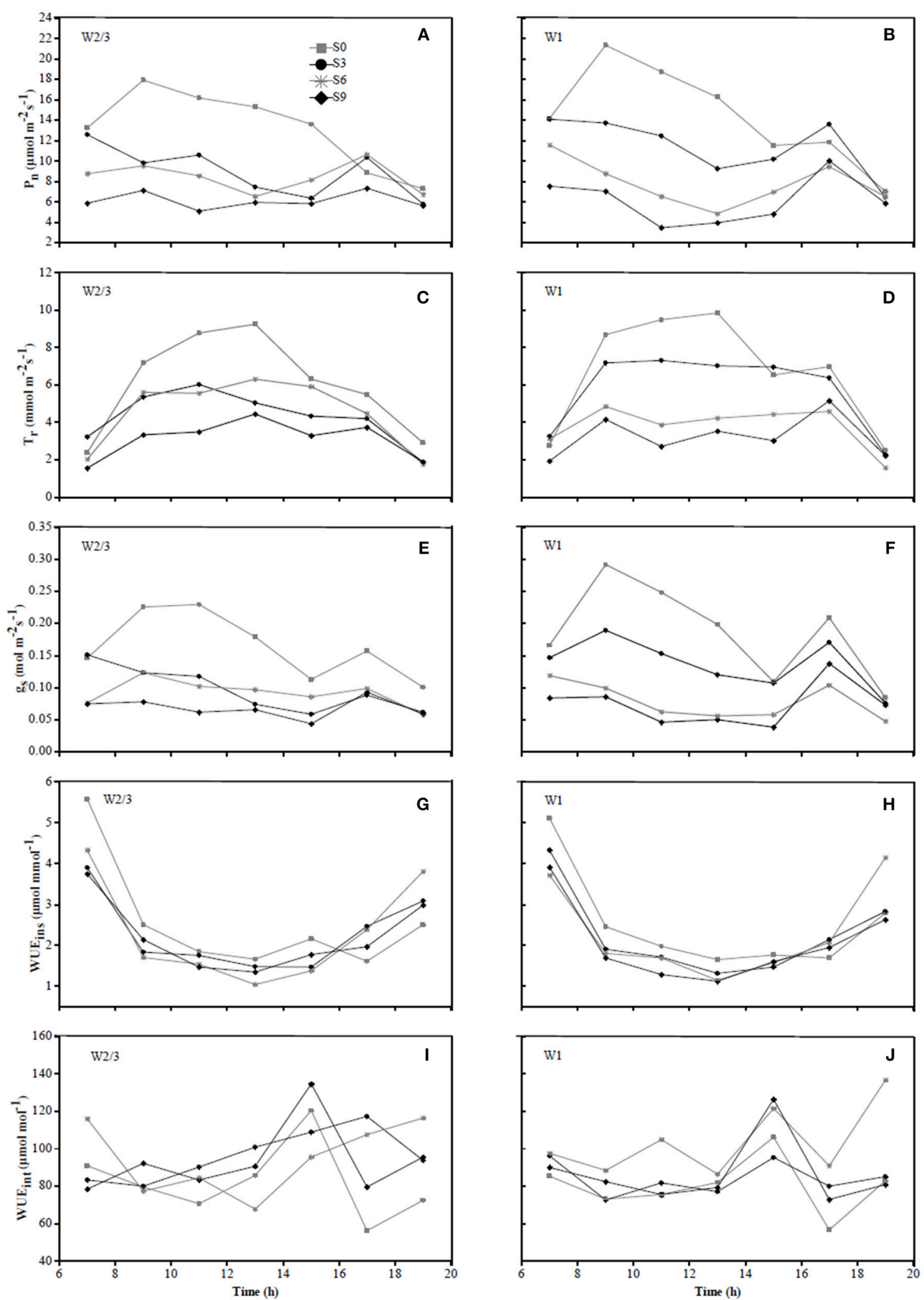

FIGURE 4 | Diurnal variations in photosynthetic rate $\left(P_{n}\right)(\mathbf{A}, \mathbf{B})$, transpiration rate $\left(T_{r}\right)(\mathbf{C}, \mathbf{D})$, stomatal conductance $\left(g_{s}\right)(\mathbf{E}, \mathbf{F})$, instantaneous water use efficiency $\left(\mathrm{WUE}_{\text {ins }}\right)(\mathbf{G}, \mathbf{H})$, and intrinsic water use efficiency $\left(\mathrm{WUE}_{\text {int }}\right)(\mathbf{I}, \mathbf{J})$ of tomato under different water treatments at fruit ripening stage (date 07/22) in 2016. 

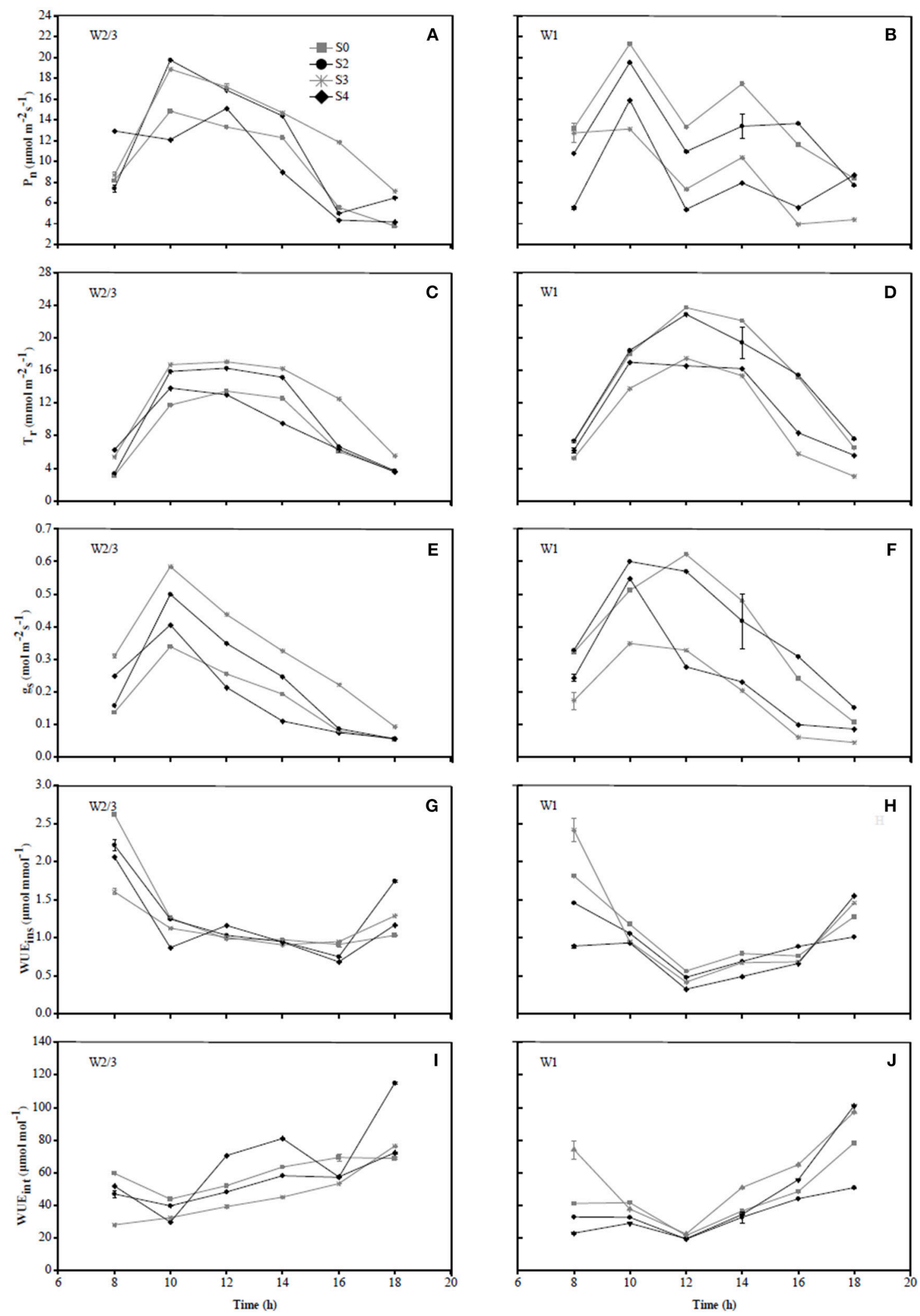

FIGURE $\mathbf{5}$ | Diurnal variations in photosynthetic rate $\left(P_{n}\right)(\mathbf{A}, \mathbf{B})$, transpiration rate $\left(T_{r}\right)(\mathbf{C}, \mathbf{D})$, stomatal conductance $\left(g_{s}\right)(\mathbf{E}, \mathbf{F})$, instantaneous water use efficiency $\left(\mathrm{WUE}_{\text {ins }}\right)(\mathbf{G}, \mathbf{H})$, and intrinsic water use efficiency $\left(\mathrm{WUE}_{\text {int }}\right)(\mathbf{I}, \mathbf{J})$ of tomato under different water treatments at fruit ripening stage (date $\left.07 / 11\right)$ in 2017. 
maximum around noon, but notably decreased after 4:00 p.m., with no sap flow measured at 9:00 p.m. (Figures 6, 7) in both experiments. In the field experiment, increases in sap flow in the morning were significantly delayed with increasing soil salt content, maximum sap flow was much lower than that in S0, and sap flow stopped earlier in the night (Figures 6C,D). The diurnal variations in sap flow under various water and salt treatments showed a single-peak curve, and sap flow rate was smaller throughout the day with increasing soil salt content under both $\mathrm{W} 2 / 3$ and $\mathrm{W} 1$ treatments (Figures $6 \mathrm{C}, \mathrm{D}, \mathrm{G}, \mathbf{H}$ ). In the greenhouse experiment, however, diurnal variations in sap flow showed a peak around noon, and another small peak was observed at 6:00 p.m. W1S2 treatment showed a relatively higher sap flow throughout the day, following the W1S3 and W2/3S0 treatments. Soil salt content significantly decreased daily sap flow (Table 4). The daily variation of sap flow rate per plant ranged from 7.96 to $31.37 \mathrm{~g} \mathrm{~h}^{-1}$ in the field experiment and from 12.52 to $36.02 \mathrm{~g} \mathrm{~h}^{-1}$ in the greenhouse experiment among various salt stresses.

The relationships between sap flow rates and climate variables under different irrigation and salt treatments at fruit development and ripening stage were established in the field and greenhouse experiments. The significant level of regression coefficients was less than 0.01 , and the most of correlation coefficients $\left(R^{2}\right)$ were higher than 0.5 (Table 5). In 2016, sap flow rate under $\mathrm{W} 2 / 3$ treatments increased linearly with increasing $\mathrm{R}_{\mathrm{s}}, \mathrm{T}_{\mathrm{a}}$, and $\operatorname{VPD}\left(R^{2}>0.5\right)$. In 2017 , sap flow also showed a positive correlation with $\mathrm{R}_{\mathrm{s}}, \mathrm{T}_{\mathrm{a}}$, and VPD under various water and salt treatments except W2/3S4 treatment $\left(R^{2}=0.41\right.$ for $\mathrm{T}_{\mathrm{a}}$ and 0.46 for VPD) (Table 5). The different regression equations indicated that the sensitivity of sap flow rates to climate variables varied with the irrigation regimes and salt treatments. In both experiments, the slopes of regression equations in no salt treatments (W2/3S0 and W1S0) were higher than those in salt stress treatments. The average $R^{2}$ between $\mathrm{T}_{\mathrm{a}}$ and VPD were lower due to the lagging effects on sap flow rates (Figures 6, $7)$. The climate variables affecting sap flow rates were ranked as $\mathrm{R}_{\mathrm{s}}>\mathrm{VPD}>\mathrm{T}_{\mathrm{a}}$.

\section{Water Use Efficiency (WUE) at Leaf and Plant Scales}

Irrigation and soil salt treatments, and their interactive effects on tomato $\mathrm{WUE}_{\text {ins }}$ and $\mathrm{WUE}_{\text {int }}$ at leaf scale, were significant during both field and greenhouse experiments (Table 4). In the field experiment of 2016, $\mathrm{WUE}_{\text {ins }}$ ranged from 1.50 to $1.95 \mu \mathrm{mol}$ $\mathrm{mmol}^{-1}$, while WUE $\mathrm{Wnt}_{\text {int }}$ ranged from 74.5 to $98.9 \mu \mathrm{mol} \mathrm{mol}^{-1}$ under different water and salt treatments. Under full and reduced irrigation, increasing salt stress decreased $P_{n}$ and $T_{r}$ and led to the reductions in $\mathrm{WUE}_{\text {ins }}$ at the leaf scale. However, compared to full irrigation, reduced irrigation (W2/3) improved $\mathrm{WUE}_{\mathrm{ins}}$ with a significant decline in $\mathrm{g}_{\mathrm{s}}$ and $\mathrm{T}_{\mathrm{r}}$ under no salt and $0.3 \%$ soil salt treatments. Under soil salt content of $0.6 \%$ and $0.9 \%$, a slight increase in $P_{n}$ and decline in $T_{r}$ resulted in higher $W_{U E}$ in the full irrigation treatment. Significant reduction in $\mathrm{g}_{\mathrm{s}}$ led to increasing $\mathrm{WUE}_{\text {int }}$ under S3 and S6 treatments compared to S0 treatment under both irrigations; however, further increases in soil salt content to $0.9 \%$ decreased the $\mathrm{WUE}_{\text {int }}$.
In the greenhouse experiment of 2017, $\mathrm{WUE}_{\mathrm{ins}}$ and $\mathrm{WUE}_{\mathrm{int}}$ varied from 0.95 to $1.28 \mu \mathrm{mol} \mathrm{mmol}{ }^{-1}$ and from 30.3 to 46.7 $\mu \mathrm{mol} \mathrm{mol}^{-1}$, respectively. Compared to full irrigation, WUE under reduced irrigation was higher under no salt and $0.2 \%$ soil salt treatment in 2016, and $\mathrm{WUE}_{\mathrm{DM}}$ and $\mathrm{WUE}_{\mathrm{Y}}$ of tomato at whole plant scale were also significantly affected by irrigation regime, soil salt content, and their interaction in 2016 (Table 4), while in 2017, the effect of irrigation regime on WUE $E_{D M}$ was not significant. In the field experiment of 2016, increasing soil salt content decreased plant dry biomass and yield, and resulted in greater decreases in whole plant $\mathrm{WUE}_{\mathrm{DM}}$ and $\mathrm{WUE}_{\mathrm{Y}}$ under both irrigation treatments. Compared to full irrigation, reduced irrigation increased both $\mathrm{WUE}_{\mathrm{DM}}$ and $\mathrm{WUE}_{\mathrm{Y}}$ under 0 and $0.3 \%$ soil salt treatments. In the greenhouse experiment of 2017 , $\mathrm{WUE}_{\mathrm{DM}}$ in $\mathrm{W} 2 / 3 \mathrm{~S} 4$ treatment was significantly lower than that in $\mathrm{W} 2 / 3 \mathrm{~S} 0$ treatment. WUEY decreased with increasing soil salt content under both irrigation treatments. WUEY under reduced irrigation was higher compared to full irrigation under $0,0.2,0.3$, and $0.4 \%$ soil salt treatments.

\section{PCA for Comprehensive Evaluation of WUE}

The results of PCA evaluation of tomato WUE at leaf and plant scales among all the treatments in the field and greenhouse experiments are shown in Figure 8. The index $y_{i}^{*}$ represents closeness of principal component of the treatment to the maximum principal; the larger the index value, the better the performance of the treatment. The PCA analysis showed that plants grown under both full and reduced irrigation with zero soil salt content (W2/3S0 and W1S0) had optimal comprehensive WUE with the highest $y_{i}^{*}$ values of 0.743 and 0.569 in the field experiment of 2016. W2/3S0 and W2/3S2 treatments ranked first and second in the greenhouse experiment of 2017, with $y_{i}^{*}$ values of 0.953 and 0.670 , respectively.

\section{DISCUSSION}

It has been suggested that high soil salt content reduces plant water uptake (Reina-Sánchez et al., 2005; Machado and Serralheiro, 2017; Phogat et al., 2018), which supported our result where root zone soil water content remained higher in containers with higher soil salt content in both reduced and full irrigation treatments during both years (Figure 2). Our results were also consistent with Reina-Sánchez et al. (2005) who reported that tomato plants grown under $75 \mathrm{mM}$ $\mathrm{NaCl}$ consumed $40 \%$ less water than plants under non-saline condition. Several mechanisms are responsible for this decrease, including modulation of underlying growth mechanisms. Saline growth medium adversely affects plant growth due to low soil osmotic potential (high osmotic stress), resulting in lower leaf and root water potentials, relative water content, and plant dehydration (Ashraf, 2004; Maggio et al., 2004). Salinity-induced ion toxicity, macro and micro nutrient deficiency (such as $\mathrm{N}, \mathrm{Ca}$, $\mathrm{K}, \mathrm{P}, \mathrm{Fe}$, and $\mathrm{Zn}$ ), as well as oxidative stresses on plants also limit water uptake from soil (Shrivastava and Kumar, 2015).

In this study, dry aboveground tomato biomass per plant was prominently affected by soil salt content, while the effect of irrigation was non-significant in both field and greenhouse experiments (Table 3). These results contrasted with those of 


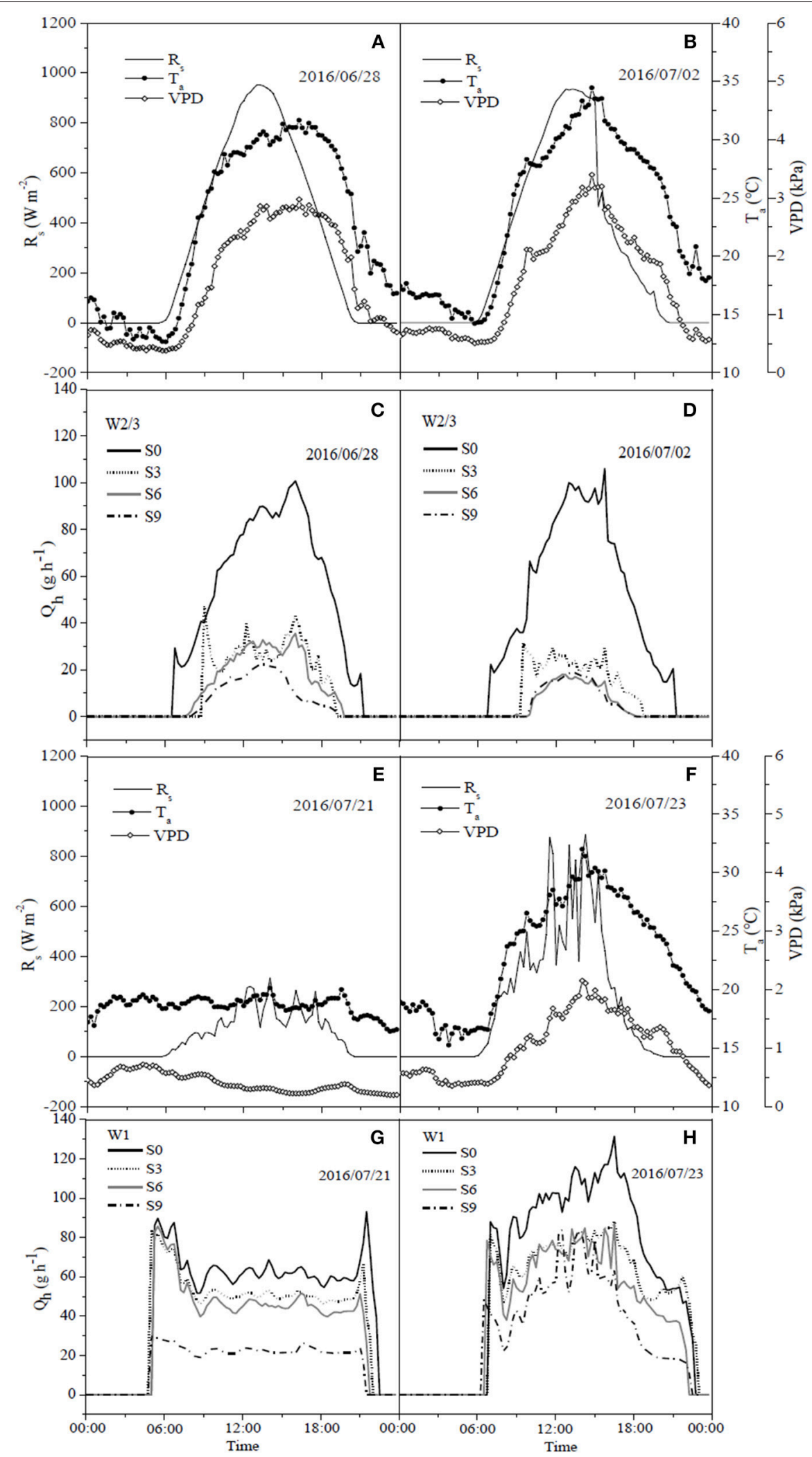

FIGURE 6 | Diurnal dynamics of hourly sap flow rate per plant $\left(Q_{h}\right)(\mathbf{C}, \mathbf{D}, \mathbf{G}, \mathbf{H})$ in tomato and corresponding solar radiation $\left(R_{S}\right)$, air temperature $\left(T_{a}\right)$ and vapor pressure deficit (VPD) (A,B,E,F) under different water and salt treatments in 2016. 


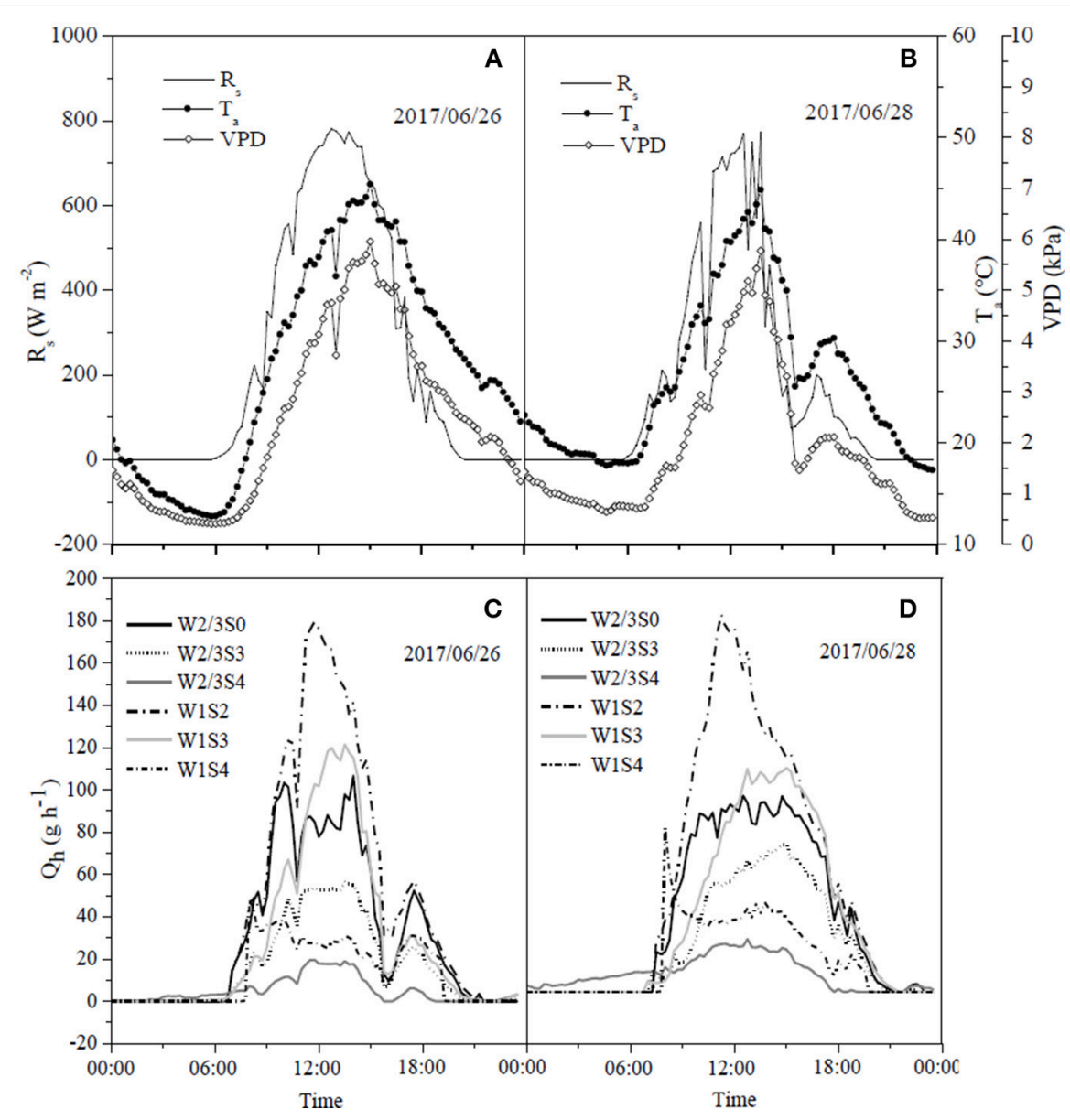

FIGURE 7 | Diurnal dynamics of hourly sap flow rate per plant $\left(Q_{h}\right)(\mathbf{C}, \mathbf{D})$ in tomato and corresponding solar radiation $\left(R_{S}\right)$, air temperature $\left(T_{a}\right)$, and vapor pressure deficit (VPD) (A,B) under different water and salt treatments in 2017.

Álvarez et al. (2018). A likely explanation is that the Álvarez et al. (2018) experiments were conducted under simulated conditions of soil cultivation and were irrigated with different levels of saline solutions. Uptake and transport rates of saline ions from root to shoot differ when plants are subjected to nutritive solution and multiple salts (Albaladejo et al., 2017) due to the competition among ions (i.e., $\mathrm{K}^{+}, \mathrm{Ca}^{2+}, \mathrm{NO}_{3}^{-} \mathrm{Na}^{+}, \mathrm{Cl}^{-}$, and $\mathrm{SO}_{4}^{2}-$ ) (Hu and Schmidhalter, 2005; Hussain et al., 2016). Most vegetable crops, including tomato, had a salinity threshold of $2.5 \mathrm{dS} \mathrm{m}^{-1}$ (Machado and Serralheiro, 2017). However, in this study, 32.9 and $20.7 \%$ yield reductions were observed at the EC of $1.03 \mathrm{dS} \mathrm{m}^{-1}$ for soil salt content of $0.3 \%$ under $2 / 3$ of full irrigation and full irrigation, respectively, in the field experiment, and 23.6 and $26.7 \%$ at the EC of $0.81 \mathrm{dS} \mathrm{m} \mathrm{m}^{-1}$ for soil salt content of $0.2 \%$ under $2 / 3$ of full irrigation and full irrigation, respectively, in the greenhouse experiment. Thus, the salinity threshold in this study was at or below $0.81 \mathrm{dS}$ $\mathrm{m}^{-1}$. This difference could result from species and different saline ions in solution and in the soil, suggesting that multiple salts in soil could further aggravate the adverse effect of salt stress on plants.
Previous studies have observed that reduced irrigation could enhance plant water use efficiency because of only slight decreases in yield but moderate declines in water application as compared to full irrigation (Kang et al., 2002, 2017; Du et al., 2010; Patanè et al., 2011; Yang et al., 2017). This study clearly illustrated that reduced irrigation improved plant yield and dry biomass WUE (WUE $\mathrm{E}_{\mathrm{Y}}$ and $\mathrm{WUE}_{\mathrm{DM}}$ ) under low soil salt content $(\mathrm{SSC} \leq 0.3 \%)$ in both experiments (Table 3). However, in 2016, WUE $_{Y}$ and $W E_{D M}$ decreased with further increases in soil salt content (SSC $\geq 0.9 \%$ ) due to the significant reduction of yield and dry biomass. Khataar et al. (2018) results for wheat WUE were similar to this study under low salinities $(\mathrm{EC} \leq 8 \mathrm{dS}$ $\mathrm{m}^{-1}$ ). However, Khataar et al. (2018) reported that bean WUE increased with increasing water and salt stresses and contradicted our results for tomato at higher soil salt content.

Tomato $\mathrm{P}_{\mathrm{n}}$, yield, dry biomass, $\mathrm{WUE}_{\mathrm{Y}}$, and $\mathrm{WUE}_{\mathrm{DM}}$ decreased with increasing soil salt content under both full and reduced irrigation during the field experiment (Table 3), indicating the source-sink relationships in which the source organ (leaves) gained the assimilation product through photosynthesis and delivered it to the sink organ (fruits) (Liu 
TABLE 5 | Relationships between sap flow rates $\left(\mathrm{Q}_{\mathrm{h}}, \mathrm{g} \mathrm{h}^{-1}\right)$ every $15 \mathrm{~min}$ and corresponding solar radiation $\left(\mathrm{R}_{\mathrm{S}}, \mathrm{W} \mathrm{m}^{-2}\right)$, air temperature $\left(\mathrm{T}_{\mathrm{a}}\right.$, $\left.{ }^{\circ} \mathrm{C}\right)$, and vapor pressure (VPD, kPa) deficit under different irrigation and salt stress treatments during 2016 and 2017 seasons.

\begin{tabular}{|c|c|c|c|c|c|c|c|c|}
\hline \multirow[t]{2}{*}{ Growth season } & \multirow[t]{2}{*}{ Treatment } & \multirow[t]{2}{*}{$\mathbf{N}$} & \multicolumn{2}{|l|}{$\mathbf{R}_{\mathbf{S}}$} & \multicolumn{2}{|l|}{$\mathbf{T}_{\mathbf{a}}$} & \multicolumn{2}{|l|}{ VPD } \\
\hline & & & Regression equation & $R^{2}$ & Regression equation & $R^{2}$ & Regression equation & $R^{2}$ \\
\hline \multirow[t]{8}{*}{2016} & W2/3S0 & 192 & $Q_{h}=(0.097 \pm 0.003) R_{s}+5.63$ & 0.86 & $\mathrm{Q}_{\mathrm{h}}=(4.91 \pm 0.16) \mathrm{T}_{\mathrm{a}}-77.25$ & 0.83 & $Q_{h}=(36.49 \pm 0.98) V P D-20.31$ & 0.88 \\
\hline & W2/3S3 & 192 & $Q_{h}=(0.032 \pm 0.001) R_{S}-0.26$ & 0.76 & $\mathrm{Q}_{\mathrm{h}}=(1.47 \pm 0.09) \mathrm{T}_{\mathrm{a}}-23.99$ & 0.59 & $Q_{h}=(11.03 \pm 0.53) V P D-7.671$ & 0.70 \\
\hline & W2/3S6 & 192 & $Q_{h}=(0.026 \pm 0.001) R_{S}-0.92$ & 0.76 & $\mathrm{Q}_{\mathrm{h}}=(1.08 \pm 0.08) \mathrm{T}_{\mathrm{a}}-17.80$ & 0.49 & $Q_{h}=(8.44 \pm 0.52) V P D-5.86$ & 0.58 \\
\hline & W2/3S9 & 192 & $Q_{h}=(0.019 \pm 0.001) R_{S}-1.112$ & 0.87 & $\mathrm{Q}_{\mathrm{h}}=(0.753 \pm 0.05) \mathrm{T}_{\mathrm{a}}-12.5$ & 0.51 & $Q_{h}=(5.83 \pm 0.35) V P D-4.14$ & 0.59 \\
\hline & W1S0 & 96 & $\mathrm{Q}_{\mathrm{h}}=(0.048 \pm 0.01) \mathrm{R}_{\mathrm{s}}+36.5$ & 0.16 & $\mathrm{Q}_{\mathrm{h}}=(3.29 \pm 0.54) \mathrm{T}_{\mathrm{a}}-29.65$ & 0.28 & $Q_{h}=(28.2 \pm 5.04) V P D+17.21$ & 0.24 \\
\hline & W1S3 & 96 & $Q_{h}=(0.039 \pm 0.01) R_{S}+30.24$ & 0.14 & $\mathrm{Q}_{\mathrm{h}}=(2.42 \pm 0.49) \mathrm{T}_{\mathrm{a}}-17.54$ & 0.20 & $Q_{h}=(20.54 \pm 4.55) V P D+17.06$ & 0.17 \\
\hline & W1S6 & 96 & $Q_{h}=(0.037 \pm 0.01) R_{S}+26.35$ & 0.14 & $\mathrm{Q}_{\mathrm{h}}=(2.19 \pm 0.47) \mathrm{T}_{\mathrm{a}}-16.59$ & 0.18 & $Q_{h}=(18.49 \pm 4.41) V P D+14.87$ & 0.15 \\
\hline & W1S9 & 96 & $Q_{h}=(1.262 \pm 0.19) R_{S}-13.22$ & 0.31 & $Q_{h}=(1.26 \pm 0.19) T_{a}-13.2$ & 0.31 & $Q_{h}=(10.81 \pm 1.79) V P D+4.71$ & 0.27 \\
\hline \multirow[t]{6}{*}{2017} & W2/3SO & 192 & $Q_{h}=(0.127 \pm 0.004) R_{s}+6.53$ & 0.86 & $\mathrm{Q}_{\mathrm{h}}=(3.50 \pm 0.13) \mathrm{T}_{\mathrm{a}}-61.12$ & 0.78 & $Q_{h}=(19.97 \pm 0.87) V P D-10.99$ & 0.73 \\
\hline & W2/3S3 & 192 & $Q_{h}=(0.08 \pm 0.002) R_{S}+2.84$ & 0.88 & $\mathrm{Q}_{\mathrm{h}}=(2.31 \pm 0.07) \mathrm{T}_{\mathrm{a}}-42.59$ & 0.86 & $Q_{h}=(13.72 \pm 0.38) V P D-10.52$ & 0.87 \\
\hline & W2/3S4 & 192 & $Q_{h}=(0.024 \pm 0.001) R_{S}+1.94$ & 0.83 & $\mathrm{Q}_{\mathrm{h}}=(0.50 \pm 0.04) \mathrm{T}_{\mathrm{a}}-6.44$ & 0.41 & $Q_{h}=(3.13 \pm 0.25) V P D-10.15$ & 0.46 \\
\hline & W1S2 & 192 & $Q_{h}=(0.209 \pm 0.005) R_{S}+5.69$ & 0.91 & $\mathrm{Q}_{\mathrm{h}}=(5.45 \pm 0.24) \mathrm{T}_{\mathrm{a}}-97.5$ & 0.74 & $Q_{h}=(31.25 \pm 1.48) V P D-19.56$ & 0.70 \\
\hline & W1S3 & 192 & $Q_{h}=(0.137 \pm 0.004) R_{s}+3.13$ & 0.86 & $\mathrm{Q}_{\mathrm{h}}=(3.96 \pm 0.12) \mathrm{T}_{\mathrm{a}}-74.82$ & 0.86 & $\mathrm{Q}_{\mathrm{h}}=(23.81 \pm 0.59) \mathrm{VPD}-20.75$ & 0.90 \\
\hline & W1S4 & 192 & $Q_{h}=(0.049 \pm 0.002) R_{S}+3.63$ & 0.69 & $\mathrm{Q}_{\mathrm{h}}=(1.30 \pm 0.08) \mathrm{T}_{\mathrm{a}}-21.32$ & 0.58 & $Q_{h}=(7.08 \pm 0.51) V P D-1.97$ & 0.50 \\
\hline
\end{tabular}

$N$, sample number; the significance of regression coefficients is less than 0.01 .

et al., 2017). Inverse relationships between $P_{n}$ and increasing salt stress are also reported by other researchers (Netondo et al., 2004; Chaves et al., 2009; Senguttuvel et al., 2014; Das et al., 2015; Negrão et al., 2017).

Stomata control, both water losses and $\mathrm{CO}_{2}$ assimilation, is a vital mechnism for plant acclimation to varying environments. Abiotic stress could suppress cell growth and photosynthesis (Wilkinson and Davies, 2002; Liu et al., 2006; Zhang et al., 2015; Álvarez et al., 2018). On the other hand, Galmés et al. (2007) reported that limited recovery of leaf hydraulic conductivity of some species after re-watering could also cause down-regulation of stomatal conductance. In addition, sodium, which was added to soil in this study, disturbs stomatal regulation by interfering with potassium uptake and transport (Farooq et al., 2015). Photosynthesis is affected by changes in stomatal conductance through the pathways noted above. All these are in good agreement with the present study, which found that $g_{s}$ was significantly positively correlated to $\mathrm{P}_{\mathrm{n}}$ as well as $\mathrm{T}_{\mathrm{r}}$ (Table 4) under various water and salinity conditions.

Wei et al. (2018) reported that reduced irrigation improved $W_{\text {Uns }}$ and $\mathrm{WUE}_{\text {int }}$ of tomato with significant decrease in gs and $\operatorname{Tr}$ at leaf scale. However, the effects of salt stress and the interaction of water and salt stresses on tomato WUE at leaf scale are still unknown. In the present study, salt stress reduced $W_{U E} E_{\text {ins }}$ under both irrigation treatments; $W_{U E}$ ins and $\mathrm{WUE}_{\text {int }}$ improved under reduced irrigation compared to full ittigation when soil salt content was less than $0.4 \%$. Both water and salt treatments together with their interaction had significant effects on $\mathrm{WUE}_{\mathrm{ins}}$ and $\mathrm{WUE}_{\mathrm{int}}$ in both experiments (Table 3). In the field experiment of 2016, WUE $\mathrm{W}_{\mathrm{ins}}$ and $\mathrm{WUE}_{\text {int }}$ of tomato increased under S6 and S9 salt treatments compared to S0 and S3 treatments only when full irrigation was applied, indicating that $g_{s}$ and $T_{r}$ were more sensitive to drought and salinity than $P_{n}$.
Diurnal variation of WUE $E_{\text {ins }}$ in Figures 4, 5 showed that $W_{U E}$ in various water regimes and soil salt contents were relatively high in the morning and late afternoon, while it remained low from 10:00 a.m. until 4:00 p.m. during both years. In contrast, diurnal variation of $\mathrm{WUE}_{\text {int }}$ remained inconsistent during 2016 as well as 2017. The ratio of $C_{i}$ to $C_{a}$ is characteristically near 0.7 for non-stressed $C_{3}$ plants (Farquhar et al., 1989). Lower $C_{i}: C_{a}$ ratios resulting from either lower stomatal conductance or higher photosynthetic capacity could improve plant $\mathrm{WUE}_{\text {int }}$ (Condon et al., 2002). Our study found that the value of $C_{i}$ : $C_{a}$ ranged from 0.5 to 0.6 in 2016, whereas it was near 0.7 in 2017 (except $\mathrm{W} 2 / 3 \mathrm{~S} 0$ treatment) (Table 3). Lower $\mathrm{C}_{\mathrm{i}}: \mathrm{C}_{\mathrm{a}}$ ratios were in accord with positive correlations with $\mathrm{T}_{\mathrm{r}}$ and $\mathrm{g}_{\mathrm{s}}$.

Liu et al. (2010) reported that on sunny days sap flow showed a single-peaked curve starting at 6:00 a.m., rapidly increased to the maximum at 1:00 p.m. with increasing $\mathrm{R}_{\mathrm{s}}$ and VPD, and decreased after 2:00 p.m. On cloudy days, sap flow exhibited a multimodal curve corresponding to the variation of $\mathrm{R}_{\mathrm{s}}$, and there was no flow during the night. In our field experiment, the sap flow also began at 6:00 a.m., but the maximum was reached at around 3:00 p.m. (Figures 6C,D). Differences in these studies are mostly due to the different atmospheric conditions $\left(\mathrm{R}_{s}, \mathrm{VPD}\right.$, and $\mathrm{T}_{\mathrm{a}}$ ). In the greenhouse experiment, sap flow exhibited a double-peaked curve with the maximum around 12:00 a.m., and the second small peak appeared at 5:30 p.m. (Figures 7C,D), which was affected by the variation of daily $R_{s}, T_{a}$, and VPD (Figures 7A,B). $\mathrm{R}_{\mathrm{s}}, \mathrm{VPD}$, and $\mathrm{T}_{\mathrm{a}}$ had positive linear relationships with sap flow, and the three variables affecting sap flow were ranked as $\mathrm{R}_{\mathrm{s}}>\mathrm{VPD}>\mathrm{T}_{\mathrm{a}}$ (Table 5) in both experiments, which was in good agreement with Liu et al. (2010) for tomato and Jiang et al. (2016) for maize.

The sap flow in our study also showed a multimodal curve on cloudy days (Figure 6G). It has been reported that reduced 

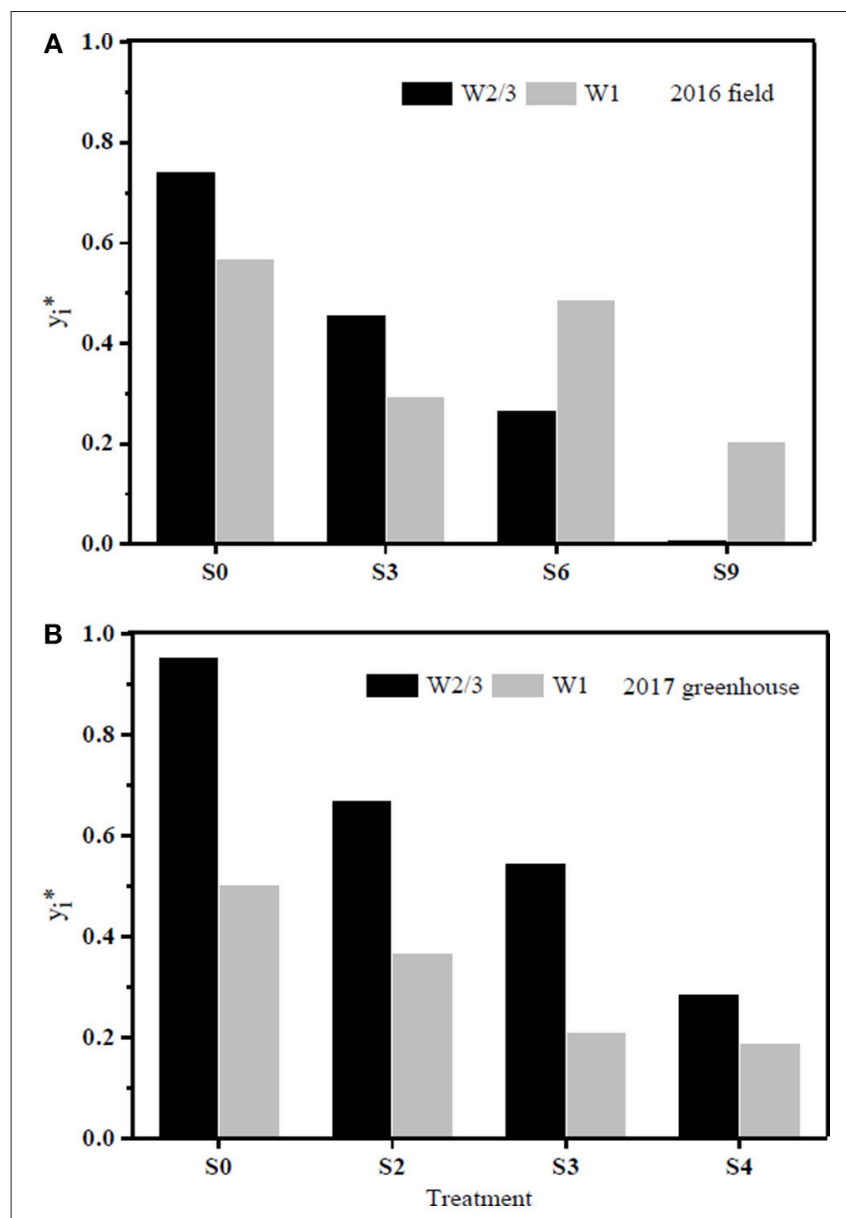

FIGURE 8 | PCA evaluation of tomato water use efficiency (WUE) at leaf and plant scales (four parameters: WUE $E_{i n s}, W U E_{i n t}, W U E_{D M}$, and WUEY) among all the treatments during 2016 (A) and 2017 (B), respectively. $y_{i}^{*}$ represents closeness of principal component of each treatment to the maximum principal.

irrigation restricted tomato sap flow (Liu et al., 2010; Qiu et al., 2015; Mao et al., 2017), whereas our study found that sap flow was significantly related to soil salt content, and salt stress prominently decreased sap flow rate and delayed start in the morning (Table 4 and Figures 6C,D). The daily variation of sap flow was possibly caused by decreasing plant size and leaf area with increasing salt stress. This result was supported by the significant positive Pearson correlation between daily sap flow rate, dry matter, and fresh yield per plant (Table 4). PCA approach is an effective tool for simplifying data sources, which can realize the accurate and comprehensive assessment of variance source after the feature extraction and dimensionality reduction. In the present study, the PCA appraisement of

\section{REFERENCES}

Ahmed, I. M., Dai, H., Zheng, W., Cao, F., Zhang, G., Sun, D., et al. (2013). Genotypic differences in physiological characteristics in the tolerance to drought and salinity combined stress between Tibetan wild and cultivated integrated WUE attributes of tomato grown under water and salt stress included four parameters $\left(W_{U E} E_{i n s}\right.$ and $W U E_{\text {int }}$ at leaf level and $W E_{Y}$ and $W E_{D M}$ at plant level). Reduced irrigation in the absence of salt stress (W2/3S0 treatments) achieved the highest comprehensive WUE among all the treatments both in 2016 and 2017; in addition, 2/3 of full irrigation combined with mild salt stress (soil salt content of $0.2 \%$ ) showed a relative higher integrated WUE in 2017 (Figure 8).

\section{CONCLUSION}

This study is important for regulating water-saving strategies for saline soil environments and improving water use efficiency at various scales $2 / 3$ of full irrigation coupled with low soil salt contents $(\mathrm{SSC} \leq 0.3 \%)$ improved $\mathrm{WUE}_{\mathrm{Y}}$ and $\mathrm{WUE}_{\mathrm{DM}}$ at the plant level, but $\mathrm{WUE}_{\mathrm{Y}}$ and $\mathrm{WUE}_{\mathrm{DM}}$ decreased under the salt stress of 0.6 and $0.9 \%$. Plants irrigated with full irrigation compensated for salt stress and maintained yield and dry biomass. $2 / 3$ of full irrigation in the absence of salt stress improved $\mathrm{P}_{\mathrm{n}}$ and reduced $\mathrm{T}_{\mathrm{r}}$, leading to the highest $\mathrm{WUE}_{\mathrm{ins}}$ at leaf level. Moderate salt stress $\left(\mathrm{SSC} \leq 0.6 \%\right.$ ) improved $\mathrm{WUE}_{\mathrm{int}}$ at leaf level under both irrigation regimes. The PCA analysis showed that $2 / 3$ of full irrigation without salt stress possessed the highest integrated WUE among all the treatments in both years; reduced irrigation coupled with mild salt stress ( $\mathrm{SSC}=0.2 \%$ ) also achieved a relative higher comprehensive WUE in 2017. Soil salt content threshold for tomato caused by multiple salts was found to be below $0.2 \%$ and is lower than thresholds reported for nutrient solution.

\section{AUTHOR CONTRIBUTIONS}

HY carried out the experiments and finished the first manuscript. MS and TD supervised the work. XM and SK helped to edit the manuscript.

\section{FUNDING}

This research received grants from the National Natural Science Foundation of China (51725904, 51621061, 51861125103), and the Discipline Innovative Engineering Plan (111 Program, B14002).

\section{ACKNOWLEDGMENTS}

The authors thank New Mexico State University Agricultural Experiment Station. The authors also thank Mr. Franklin Sholedice of New Mexico State University for editing the manuscript. barley. Plant Physiol. Biochem. 63, 49-60. doi: 10.1016/j.plaphy.2012. 11.004

Albaladejo, I., Meco, V., Plasencia, F., Flores, F. B., Bolarin, M. C., and Egea, I. (2017). Unravelling the strategies used by the wild tomato species Solanum pennellii to confront salt stress: from leaf anatomical adaptations to molecular 
responses. Environ. Exp. Bot. 135, 1-12. doi: 10.1016/j.envexpbot.2016. 12.003

Álvarez, S., Rodríguez, P., Broetto, F., and Sánchez-Blanco, M. J. (2018). Long term response and adaptive strategies of Pistacia Lentiscus under moderate and severe deficit irrigation and salinity: osmotic and elastic adjustment, growth, ion uptake and photosynthetic activity. Agric. Water Manage. 202, 253-262. doi: 10.1016/j.agwat.2018.01.006

Ashraf, M. (2004). Some important physiological selection criteria for salt tolerance in plants. Flora 199, 361-376. doi: 10.1078/0367-2530-00165

Baath, G. S., Shukla, M. K., Bosland, P. W., Steiner, R. L., and Walker, S. J. (2017). Irrigation water salinity influences at various growth stages of Capsicum annuum. Agric. Water Manage. 179, 246-253. doi: 10.1016/j.agwat.2016.05.028

Bierhuizen, J. F., and Slatyer, R. O. (1965). Effect of atmospheric concentration of water vapour and $\mathrm{CO}_{2}$ in determining transpirationphotosynthesis relationships of cotton leaves. Agric. Meteorol. 2, 259-270. doi: 10.1016/0002-1571(65)90012-9

Chaves, M. M., Flexas, J., and Pinheiro, C. (2009). Photosynthesis under drought and salt stress: regulation mechanisms from whole plant to cell. Ann. Bot. 103, 551-560. doi: 10.1093/aob/mcn 125

Chen, J. L., Kang, S. Z., Du, T. S., Qiu, R. J., Guo, P., and Chen, R. Q. (2013). Quantitative response of greenhouse tomato yield and quality to water deficit at different growth stages. Agric. Water Manage. 129, 152-162. doi: 10.1016/j.agwat.2013.07.011

Condon, A. G., Richards, R. A., Rebetzke, G. J., and Farquhar, G. D. (2002). Improving intrinsic water use efficiency and crop yield. Crop Sci. 42, 122-131. doi: $10.2135 /$ cropsci2002.1220

Cosić, M., Djurović, N., Todorović, M., Maletić, R., Zećević, B., and Strićević, R. (2015). Effect of irrigation regime and application of kaolin on yield, quality and water use efficiency of sweet pepper. Agric. Water Manage. 159, 139-147. doi: 10.1016/j.agwat.2015.05.014

Das, P., Nutan, K. K., Singla-Pareek, S. L., and Pareek, A. (2015). Understanding salinity responses and adopting 'omics-based' approaches to generate salinity tolerant cultivars of rice. Front. Plant Sci. 6:712. doi: 10.3389/fpls.2015.00712

De Swaef, T., and Steppe, K. (2010). Linking stem diameter variations to sap flow, turgor and water potential in tomato. Funct. Plant Biol. 37, 429-438. doi: 10.1071/FP09233

Deb, S. K., Sharma, P., Shukla, M. K., and Sammis, T. W. (2013). Drip-irrigated pecan seedling response to irrigation water salinity. Hortscience 48, 1548-1555. doi: 10.21273/HORTSCI.48.12.1548

Du, T. S., Kang, S. Z., Sun, J. S., Zhang, X. Y., and Zhang, J. H. (2010). An improved water use efficiency of cereals under temporal and spatial deficit irrigation in north China. Agric. Water Manage. 97, 66-74. doi: 10.1016/j.agwat.2009.08.011

Du, T. S., Kang, S. Z., Zhang, J. H., and Davies, W. (2015). Deficit irrigation and sustainable water-resource strategies in agriculture for China's food security. J. Exp. Bot. 66, 2253-2269. doi: 10.1093/jxb/erv034

Farooq, M., Hussain, M., Wakeel, A., and Siddique, K. H. M. (2015). Salt stress in maize: effects, resistance mechanisms, and management. A review. Agron. Sustain. Dev. 35, 461-4811. doi: 10.1007/s13593-015-0287-0

Farquhar, G. D., Ehleringer, J. R., and Hubick, K. T. (1989). Carbon isotope discrimination and photosynthesis. Annu. Rev. Plant Physiol. Plant Mol. Biol. 40, 503-537. doi: 10.1146/annurev.pp.40.060189.002443

Farquhar, G. D., and Sharkey, T. D. (1982). Stomatal conductance and photosynthesis. Annu. Rev. Plant Physiol. 33, 317-345. doi: 10.1146/annurev.pp.33.060182.001533

Flores, A., Shukla, M. K., Daniel, D., Ulery, A., Schutte, B., Pichionni, G., et al. (2016). Evapotranspiration changes with irrigation using saline groundwater and RO concentrate. J. Arid Environ. 131, 35-45. doi: 10.1016/j.jaridenv.2016.04.003

Flores, A., Shukla, M. K., Schutte, B., Picchioni, G., and Daniel, D. (2017). Physiologic response of six plant species grown in two contrasting soils and irrigated with brackish groundwater and RO concentrate. Arid Land Res. Manage. 31, 182-203. doi: 10.1080/15324982.2016.1275068

Galli, V., Messias, R. D. S., Perin, E. C., Borowski, J. M., Bamberg, A. L., and Rombaldi, C. V. (2016). Mild salt stress improves strawberry fruit quality. $L W T$ 73, 693-699. doi: 10.1016/j.lwt.2016.07.001

Galmés, J., Flexas, J., Savé, R., and Medrano, H. (2007). Water relations and stomatal characteristics of Mediterranean plants with different growth forms and leaf habits: responses to water stress and recovery. Plant Soil 290, 139-155. doi: 10.1007/s11104-006-9148-6

$\mathrm{Hu}, \mathrm{Y}$., and Schmidhalter, U. (2005). Drought and salinity: a comparison of their effects on mineral nutrition of plants. J. Plant Nutr. Soil Sci. 168, 541-549. doi: 10.1002/jpln.200420516

Hussain, M. I., Lyra, D. A., Farooq, M., Nikoloudakis, N., and Khalid, N. (2016). Salt and drought stresses in safflower: a review. Agron. Sustain. Dev. 36:4. doi: 10.1007/s13593-015-0344-8

Jiang, X. L., Kang, S. Z., Li, F. S., Du, T. S., Tong, L., and Comas, L. (2016). Evapotranspiration partitioning and variation of sap flow in female and male parents of maize for hybrid seed production in arid region. Agric. Water Manage. 176, 132-141. doi: 10.1016/j.agwat.2016.05.022

Kang, S. Z., Hao, X. M., Du, T. S., Tong, L., Su, X. L., Lu, H. N., et al. (2017). Improved agricultural water productivity to ensure food security in China under changing environment: from research to practice. Agric. Water Manage. 179, 5-17. doi: 10.1016/j.agwat.2016.05.007

Kang, S. Z., Zhang, L., Liang, Y. L., Hu, X. T., Cai, H. J., and Gu, B. J. (2002). Effects of limited irrigation on yield and water use efficiency of water wheat in the Loess Plateau of China. Agric. Water Manage. 55, 203-216. doi: 10.1016/S0378-3774(01)00180-9

Katerji, N., Mastrorilli, M., Lahmer, F. Z., Maalouf, F., and Oweis, T. (2011). Faba bean productivity in saline-drought conditions. Eur. J. Agron. 35, 2-12. doi: 10.1016/j.eja.2011.03.001

Khataar, M., Mohhamadi, M. H., and Shabani, F. (2018). Soil salinity and matric potential interaction on water use, water use efficiency and yield response factor of bean and wheat. Sci. Rep. 8:2679. doi: 10.1038/s41598-018-20968-Z

Liu, F. L., Shahnazari, A., Andersen, M. N., Jacobsen, S. E., and Jensen, C. R. (2006). Physiological response of potato (Solanum tuberosum L.) to partial root-zone drying: ABA signaling, leaf gas exchange, and water use efficiency. J. Exp. Bot. 57, 3727-3735. doi: 10.1093/jxb/erl131

Liu, H., Sun, J. S., Duan, A. W., Liu, Z. G., and Liang, Y. Y. (2010). Experiments on variation of tomato sap flow under drip irrigation conditions in greenhouse. Trans. CSAE 26, 77-82. doi: 10.3969/j.issn.1002-6819.2010.10.012

Liu, Y., Li, P., Xu, G. C., Xiao, L., Ren, Z. P., and Li, Z. B. (2017). Growth, morphological, and physiological responses to drought stress in bothriochloa ischaemum. Front. Plant Sci. 8:230. doi: 10.3389/fpls.2017.00230

Machado, R. M. A., and Serralheiro, R. P. (2017). Soil Salinity: effect on vegetable crop growth. Management practices to prevent and mitigate soil salinization. Horticulturae 3:30. doi: 10.3390/horticulturae3020030

Maggio, A., De Pascale, S., Angelino, G., Ruggiero, C., and Barbieri, G. (2004). Physiological response of tomato to saline irrigation in long-term salinized soils. Eur. J. Agron. 21, 149-159. doi: 10.1016/S1161-0301(03)00092-3

Mao, H. P., Ikram, U., Ni, J. H., Qaiser, J., and Ahmad, A. (2017). Estimating tomato water consumption by sap flow measurement in response to water stress under greenhouse conditions. J. Plant Interact. 12, 402-413. doi: 10.1080/17429145.2017.1373869

Martínez, J. P., Silva, H., Ledent, J. F., and Pinto, M. (2007). Effect of drought stress on the osmotic adjustment, cell wall elasticity and cell volume of six cultivars of common beans (Phaseolus vulgaris L.). Eur. J. Agron. 26, 30-38. doi: 10.1016/j.eja.2006.08.003

Mittler, R. (2006). Abiotic stress, the field environment and stress combination. Trends Plant Sci. 11, 15-19. doi: 10.1016/j.tplants.2005.11.002

Munns, R. (2002). Comparative physiology of salt and water stress. Plant Cell Environ. 25, 239-250. doi: 10.1046/j.0016-8025.2001.00808.x

Negrão, S., Schmöckel, S. M., and Tester, M. (2017). Evaluating physiological response of plants to salinity. Ann. Bot. 119, 1-11. doi: 10.1093/aob/mcw191

Netondo, G. W., Onyango, J. C., and Beck, E. (2004). Sorghum and Salinity: II. Gas exchange and chlorophyll fluorescence of sorghum under salt stress. Crop Sci. 44, 806-811. doi: 10.2135/cropsci2004.8060

Niu, S. L., Xing, X. R., Zhang, Z., Xia, J. Y., Zhou, X. H., Song, B., et al. (2011). Water use efficiency in response to climate change: from leaf to ecosystem in a temperate steppe. Glob. Change Biol. 17, 1073-1082. doi: 10.1111/j.1365-2486.2010.02280. $\mathrm{x}$

Norman, J. M. (1998). An Introduction to Environmental Biophysics. New York, NY: Springer-Verlag.

Patanè, C., Tringali, S., and Sortino, O. (2011). Effects of deficit irrigation on biomass, yield, water productivity and fruit quality of processing tomato 
under semi-arid Mediterranean climate conditions. Sci. Hortic. 129, 590-596. doi: 10.1016/j.scienta.2011.04.030

Patil, N. M. (2012). Adaptations in response to salinity in Safflower Cv. Bhima. Asian J. Crop Sci. 4, 50-62. doi: 10.3923/ajcs.2012.50.62

Phogat, V., Pitt, T., Cox, J. W., Šimunek, J., and Skewes, M. A. (2018). Soil water and salinity dynamics under sprinkler irrigated almond exposed to a varied salinity stress at different growth stages. Agric. Water Manage. 201, 70-82. doi: 10.1016/j.agwat.2018.01.018

Qadir, M., Quillérou, E., Nangia, V., Murtaza, G., Singh, M., Thomas, R. J., et al. (2014). Economics of salt-induced land degradation and restoration. Nat. Resour. Forum 38, 282-295. doi: 10.1111/1477-8947.12054

Qiu, R. J., Du, T. S., Kang, S. Z., Chen, R. Q., and Wu, L. S. (2015). Influence of water and nitrogen stress on stem sap flow of tomato grown in a solar greenhouse. J. Am. Soc. Hortic. Sci. 140, 111-119. doi: 10.21273/JASHS.140.2.111

Reina-Sánchez, A., Romero-Aranda, R., and Cuartero, J. (2005). Plant water uptake and water use efficiency of greenhouse tomato cultivars irrigated with saline water. Agric. Water Manage. 78, 54-66. doi: 10.1016/j.agwat.2005.04.021

Romero-Aranda, R., Soria, T., and Cuartero, J. (2001). Tomato plant-water uptake and plant-water relationships under saline growth conditions. Plant Sci. 160, 265-272. doi: 10.1016/S0168-9452(00)00388-5

Schiattone, M. I., Candido, V., Cantore, V., Montesano, F. F., and Boari, F. (2017). Water use and crop performance of two wild rocket genotypes under salinity conditions. Agric. Water Manage. 194, 214-221. doi: 10.1016/j.agwat.2017.09.009

Senguttuvel, P., Vijayalakshmi, C., Thiyagarajan, K., Kannanbapu, J. R., Kota, S., Padmavathi, G., et al. (2014). Changes in photosynthesis, chlorophyll fluorescence, gas exchange parameters and osmotic potential to salt stress during early seedling stage in rice (Oryza sativa L.). SABRAO J. Breed. Genet. 46, 120-135.

Shrivastava, P., and Kumar, R. (2015). Soil Salinity: a serious environmental issue and plant growth promoting bacteria as one of the tools for its alleviation. Saudi J. Biol. Sci. 22, 123-131. doi: 10.1016/j.sjbs.2014.12.001

Shukla, M. K., Lal, R., and Ebinger, M. (2006). Determining soil quality indicators by factor analysis. Soil Tillage Res. 87, 194-204. doi: 10.1016/j.still.2005.03.011

Siddiqi, E. H., Ashraf, M., Al-Qurainy, F., and Akram, N. A. (2011). Salt-induced modulation in inorganic nutrients, antioxidant enzymes, proline content and seed oil composition in safflower (Carthamus tinctorius L.). J. Sci. Food Agric. 91, 2785-2793. doi: 10.1002/jsfa.4522

Sinclair, T. R., Tanner, C. B., and Bennett, J. M. (1984). Water use efficiency in crop production. AIBS 34, 36-40. doi: 10.2307/1309424

Trambouze, W., and Voltz, M. (2001). Measurement and modeling of the transpiration of a Mediterranean vineyard. Agric. Water Manage. 107, 153-166. doi: 10.1016/S0168-1923(00)00226-4
Unesco Water Portal (2007). Available online at: http://www.unesco.org/water (Accessed October 25, 2007).

Wang, C. X., Gu, F., Chen, J. L., Yang, H., Jiang, J. J., Du, T. S., et al. (2015). Assessing the response of yield and comprehensive fruit quality of tomato grown in greenhouse to deficit irrigation and nitrogen application strategies. Agric. Water Manage. 161, 9-19. doi: 10.1016/j.agwat.2015.07.010

Wang, Y. S., Liu, F. L., Andersen, M. N., and Jensen, C. R. (2010). Improved plant nitrogen nutrition contributes to higher water use efficiency in tomatoes under alternate partial root-zone irrigation. Funct. Plant Biol. 37, 175-182. doi: 10.1071/FP09181

Wei, Z. H., Du, T. S., Li, X. N., Fang, L., and Liu, F. L. (2018). Interactive effects of $\mathrm{CO}_{2}$ concentration elevation and nitrogen fertilization on water and nitrogen use efficiency of tomato grown under reduced irrigation regimes. Agric. Water Manage. 202, 174-182. doi: 10.1016/j.agwat.2018.02.027

Wei, Z. H., Du, T. S., Zhang, J., Xu, S. J., Cambre, P. J., and Davies, W. J. (2016). Carbon isotope discrimination shows a higher water use efficiency under alternate partial root-zone irrigation of field-grown tomato. Agric. Water Manage. 165, 33-43. doi: 10.1016/j.agwat.2015.11.009

Wilkinson, S., and Davies, W. J. (2002). ABA-based chemical signaling: the coordination of responses to stress in plants. Plant Cell Environ. 25, 195-210. doi: 10.1046/j.0016-8025.200.00824.x

Yang, H., Du, T. S., Qiu, R. J., Chen, J. L., Li, Y., Wang, C. X., et al. (2017). Improved water use efficiency and fruit quality of greenhouse crops under regulated deficit irrigation in northwest China. Agric. Water Manage. 179, 193-204. doi: 10.1016/j.agwat.2016.05.029

Zhang, P., Senge, M., and Dai, Y. (2016). Effects of salinity stress on growth, yield, fruit quality and water use efficiency of tomato under hydroponics system. Rev. Agric. Sci. 4, 46-55. doi: 10.7831/ras.4.46

Zhang, X. Z., Ervin, E. H., Liu, Y. M., Hu, G. F., Shang, C., Fukao, T., et al. (2015). Differential response of antioxidants, abscisic acid, and auxin to deficit irrigation in two perennial ryegrass cultivars contrasting in drought tolerance. J. Am. Soc. Hortic. Sci. 140, 562-572. doi: 10.21273/JASHS.140.6.562

Conflict of Interest Statement: The authors declare that the research was conducted in the absence of any commercial or financial relationships that could be construed as a potential conflict of interest.

Copyright (c) 2019 Yang, Shukla, Mao, Kang and Du. This is an open-access article distributed under the terms of the Creative Commons Attribution License (CC BY). The use, distribution or reproduction in other forums is permitted, provided the original author(s) and the copyright owner(s) are credited and that the original publication in this journal is cited, in accordance with accepted academic practice. No use, distribution or reproduction is permitted which does not comply with these terms. 